ISSN: 2146-3042

DOI: $10.25095 /$ mufad.607203

\title{
BDG Matrisi’nin Yönetim Muhasebesinde Kullanılabilirliği ve Karar Almadaki Rolü*
}

\author{
Miraç Sema ÜLKER ${ }^{* *} \quad$ Pinar DALOĞLU ${ }^{* * *}$
}

\section{ÖZET}

Dünya ekonomisindeki gelişmeler ve teknolojik yenilikler ile birlikte, ülkelerin yanı sıra firmalar arasındaki rekabet de artmıştır. Üretim faaliyetinde bulunan işletmelerin, küresel rekabete uyum sağlayabilmek için, firma kârlılığını maksimize etme ve dolayısı ile mamul maliyetlerini belirleme ve planlama ihtiyaçları artmaktadır. Mamul maliyetlerinin planlanmasının yanı sira hangi mamullerin işletmeye katkısının daha fazla olduğu ve üretimine devam edilmesinin gerektiği hakkında karar vermeye yönelik pek çok yöntem geliştirilmektedir. Pazarlama ve stratejik karar verme açısından Boston Danışma Grubu (BDG), 1963 yılında, mamullerin ve iş birimlerinin etkinliğinin belirlenmesine yardımcı olması için bir portföy matrisi geliştirmiştir. Bu yaklaşım pek çok araştırmaya konu olmuştur. Bu çalı̧̧mada, BDG matrisinin maliyet ve yönetim muhasebesi kararlarında kullanılabilirliği araştırılmaktadır. Öncelikle BDG Portföy Matrisi'nin uygulanması ve yorumlanmasl, sonrasinda pazarlama ve stratejik yönetim kararlarındaki işleyişi incelenmektedir. Maliyet ve yönetim muhasebesi kararlarında matrisin kullanılabilirliği teorik açıdan araştırıldlktan sonra, bir uygulama üzerinde çalışma tamamlanmaktadır.

Anahtar Kelimeler: Boston Danışma Grubu Matrisi, Maliyet, Yönetim Muhasebesi

Jel Sintflandirmast: M40, M41, M49.

The Availability of BDG Matrix in Management Accounting and It's Role in Decision Making ABSTRACT

The competition between the countries as well as the companies has increased with the developments in the world economy and technological innovations, In order to be able to adapt to global competition, the enterprises that are in the production activities have to increase their profitability by calculating product costs and cost planning. In addition to the planning of product costs, many methods are developed to decide which products have more contribution to the enterprise. In terms of marketing and strategic decision-making, the Boston Consulting Group (BCG) developed a portfolio matrix in 1963 to help determine the effectiveness of products and business units. This approach has been the subject of many researches. In this study, the usability of BCG matrix in cost and managerial accounting decisions is investigated. First of all, the implementation and interpretation of the BCG Portfolio Matrix and the functioning of marketing and strategic management decisions are examined. After the theoretical investigation of the usability of the matrix in cost and managerial accounting decisions, the study is completed with a practice.

Keywords: Boston Consulting Group Matrix, Cost, Managerial Accounting.

Jel Classification: M40, M41, M49.

Makale Gönderim Tarihi: 01.06.2019

Makale Kabul Tarihi: 01.08.2019

Makale Türü: Vak’a (Örnek Olay) Çalışması

\footnotetext{
* Bu çalışma, 1-4 Mayıs 2019 tarihlerinde Bursa'da düzenlenen V. Uluslararası Muhasebe ve Finans Sempozyumu'nda özet bildiri olarak sunulmuştur

${ }^{* *}$ Prof., T.C. İstanbul Üniversitesi, İşletme Fakültesi, Muhasebe ABD. Öğretim Üyesi, ORCID: 0000-0002-9959-6291
${ }^{* * *}$ Dr. Öğr. Üyesi, T.C. İstanbul Arel Üniversitesi, İktisadi ve İdari Bilimler Fakültesi, İşletme Bölümü Ögretim Üyesi,
pinardaloglu@arel.edu.tr, ORCID: 0000-0002-1456-4603
} 


\section{GİRiş}

Portföy analizleri genel olarak, yatırımlarını çeşitlendirmiş bir işletmenin, stratejik iş birimi olarak mevcut yatırımlarını kullanılan çeşitli ölçülere göre değerlendirme, gelecekte sağlayacakları yarar ve olanakları tahmin etmek ve bu değerlendirmeden hareket ederek eldeki kaynakların ne şekilde kullanılması gerektiği hakkında karara varma sürecidir. $\mathrm{Bu}$ nedenle portföy analizleri, işletmelerin pazar, maliyet ve rekabet koşulları hakkında bilgi veren yöntemlerdir (Eren,2013:30). Bu araştırmada portföy matrisinin kavramsal yapısı, stratejik önemi literatür çalışması yapılmış ve maliyet ve yönetim muhasebesinde BDG portföy matrisinin uygulanabilirliği, verilerin bilgi haline getirilmesinde gerekli koşulların sağlanarak karar alıcılara durumsal raporlamanın hazırlanması amaçlanmıştır. Bir şirket uygulaması ile yönetim muhasebesi açısından satış- maliyet-katkı ilişkisinin portföy matrisi oluşturulmuştur.

\section{BOSTON DANIŞMA GRUBU (BDG) PORTFÖY MATRİSİ VE YORUMLANMASI}

Stratejik planlamalarda en çok kullanılan portföy matrisi, 1963 yılında Boston Danışma Grubu (BDG) tarafindan geliştirilmiştir. (https://www.bcgperspectives.com, 2015) Literatürdeki çalışmalarda, "Mamul (veya Ürün) Portföy Matrisi", "İş Birimleri Portföy Yönetim Matrisi" ve "Büyüme/Pazar Payı Matrisi" gibi adlandırılmaktadır. Fakat genel olarak "BDG Portföy Matrisi" olarak bilinmektedir.

Farklı şekillerde isimlendirilmesinin temel nedeni, BDG Portföy Matrisi'nin, Stratejik İş Birimleri (SİB) veya mamullerin stratejik planlamaları için kullanılabiliyor olmasıdır. $\mathrm{Bu}$ nedenle BDG matrisi, hem pazarlama alanında hem de stratejik yönetim alanında tercih edilmektedir. Bu yaklaşım, pazarlamada, işletmelerin rekabet stratejilerinin oluşturulmasında ürünler bazında karar almak açısından önemlidir. Stratejik yönetimde ise, belirlenen SİB'ler ile ilgili üst yönetim kararlarının alınması açısından önemlidir.

Ürün veya SİB portföy analizi işletmeye ait satış büyüme ve göreceli pazar payı matrisinin oluşturulması ile yapılmaktadır. Öncelikle, her ürün veya SİB için pazardaki rakibine oranla pazar payı hesaplanmaktadır. Sonrasında bu ürün veya SİB için yıldan yıla gözlemlenen pazar büyüme oranı belirlenmekte ve ürün veya SİB'ler işletmeye sağladığ 1 satış hasılatı ile orantılı çapa sahip bir daire kullanılarak matrise yerleştirilmektedir. Böylece, ürün veya SİB'ler arasında kıyaslama olanağına sahip olunmaktadır.(Eren, 2013:304) Göreceli pazar payı ve pazarın büyüme hızı aşağıdaki formüller yardımı ile hesaplanabilecektir: (Çetinkaya,2006: 64-66)

$$
\text { Göreceli Pazar Payı }=\frac{\text { İşletmenin SİB Satış Hasılatı }}{\text { En Büyük Rakibin Satış Hasılatı }}
$$




$\begin{gathered}\text { Pazar Büyüme Hızı } \\ (\%)\end{gathered}=\frac{(\text { Cari Yıl Satışları }- \text { Geçmiş Yı1 Satışları) }}{\text { Geçmiş Yıl Satışları }} \quad$ x 100

Matrisin orta noktası, normal büyüme oranı ile göreceli pazar payı eşik değerinin kesiştiği noktadır. Göreceli pazar payının eşik değeri, pazar büyüme hızı yüksek sektörler için 1,5, düşük olan sektörler için ise 1 olarak kabul edilmektedir. (Çetinkaya,2006: 66)

Tablo 1. BDG Portföy Matrisi
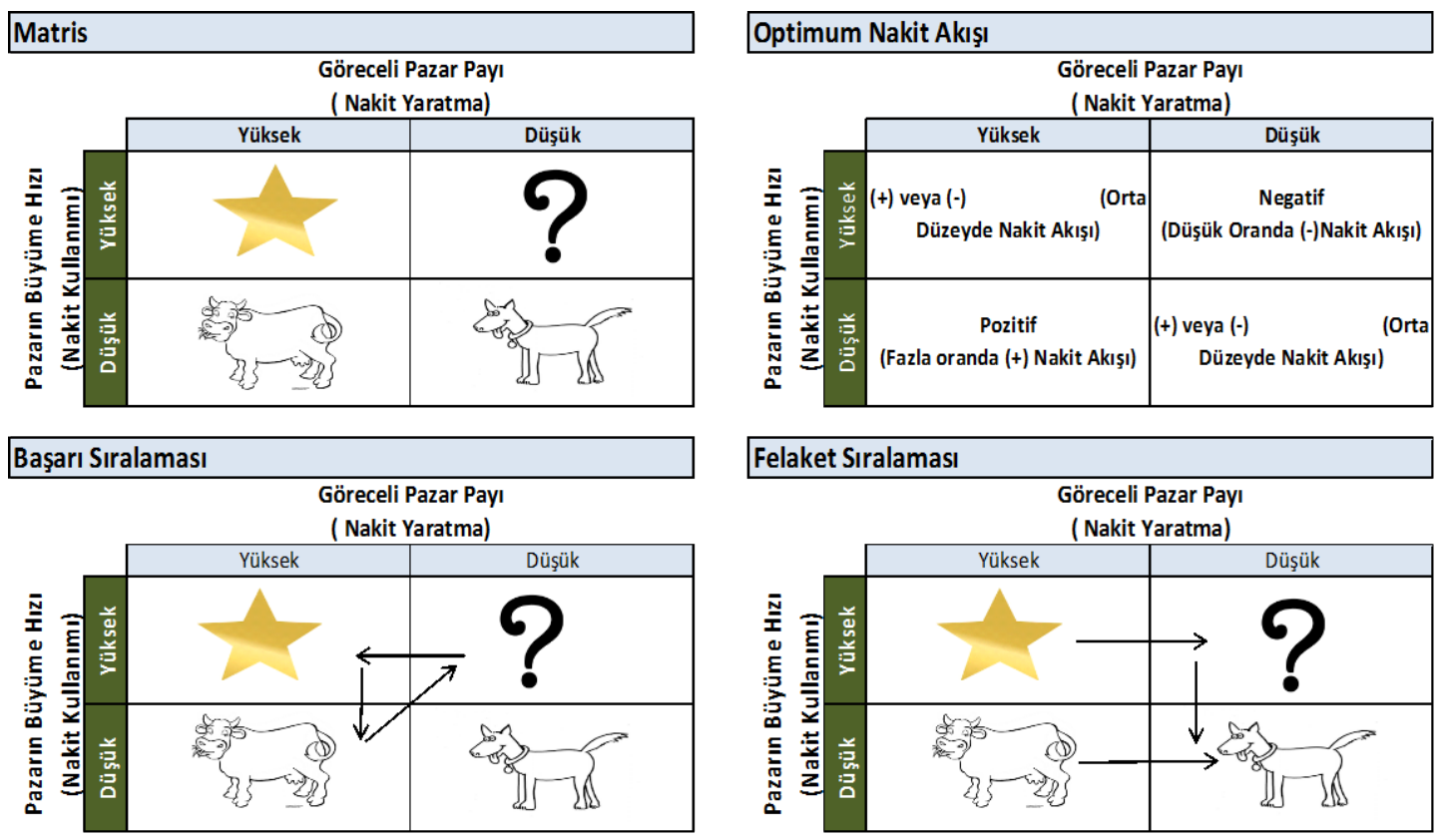

Kaynak: https://www.bcgperspectives.com/content/Classics/strategy_the_product_portfolio.

Ürünler veya SİB'ler, BDG Portföy matrisinde bulunduğu konuma göre yorumlanmalıdır. Yıldızlar, pazar payının ve pazarın büyüme hızının, nakit yaratma ve nakit kullanmanın yüksek olduğu bölgedir. Bu noktada pazarın büyüme hızı yüksek olduğu için, rekabet yüksektir. Yıldızlardaki ürün veya SİB, pazarın büyüme hızının yavaşlaması ile sağmal nakit ineklerine geçmeyi bekleyecek şekilde durumunu korumalıdır. Sağmal nakit inekleri, yüksek pazar payına karşılık düşük pazar payı büyümesine sahip, düşük nakit kullanımı gerektiren fakat fazla miktarda nakit yaratan ürün veya SİB'lerdir. İşletmenin diğer faaliyetlerine nakit kaynağı sağlarlar ve işletmelerin geleceğinde önemli rol oynarlar. İşletmenin soru işaretleri, yıldızları ve uyuz köpekleri için finans kaynağı yaratmaktadırlar. Uyuz köpekler, nakit ihtiyacı duymayan ve nakit yaratmayan, düşük pazar büyümesi ve pazar payına sahip alandır. İşletmelerin ancak prestijlerini korumak amacıyla faaliyetlerine devam etmeleri durumunda göz ardı edilmelidirler. Aksi taktirde satılmaları veya tasfiye edilmeleri en uygun karar olacaktır (Miller,1998:260). Soru işaretlilerinin durumu ise rakiplerine bağlı olarak değişecektir. İlerleyen dönemlerde, yıldızlara geçebilecekleri gibi uyuz köpeklere de geçebilecektir. İki strateji önerilmektedir: nakit akışı temin edilerek büyüme stratejileri 
geliştirilebilir veya kendi haline bırakılarak ilerleyen dönemlerde tasfiyesi gerçekleştirilebilir. $\mathrm{Bu}$ belirsizlik nedeni ile soru işareti ismini almaktadır (Ülgen ve Mirze, 2013:238)

Matrisin hazırlanmasında bazı problemler bulunmaktadır. Bu problemler; zor, zaman gerektiren ve maliyetli bir uygulama olması şeklinde sınıflandırılabilmektedir. Yönetimsel olarak SİB'lerin göreceli pazar payının ve pazar büyüme hızının belirlenmesinin güç olduğu düşüne bilinmektedir. Ayrıca matris, işletmelerin mevcut durumuna odaklanmakta fakat gelecek planlarına az yer vermektedir ( Kotler ve Armstrong, 2012: 67).

\subsection{Kurumsal Strateji Açısından Matrisin Yorumlanması}

İşletmeler ya da iş birimleri işlerin büyütülmesi, küçültülmesi, korunması veya bu işlerin aynı anda veya birbiri ardına uygulanarak bir arada yapılması konusunda uygun stratejiler geliştirirler. $\mathrm{Bu}$ stratejilerden bazıları işletmelerin üst yönetimlerinin sorumluluğunda hazırlanıp uygulanılırken, bazıları bölümlerin ve departmanların sorumluluğunda hazırlanır ve uygulanır. Örneğin bölgesel bir pazarın genişletilmesi hususundaki stratejiler işlevseldir ve genellikle üst yönetimin sadece onaylama aşamasında rol alır. Fakat işletmenin yeni ve farklı ürün geliştirerek yeni pazar alanına girmesi, üst yönetim düzeyinde geliştirilen ve uygulanan bir büyüme stratejisidir. $\mathrm{Bu}$ stratejiler "Kurumsal Stratejiler" olarak adlandırılmaktadır ve işletmenin uzun dönemde, karşılaştırmalı üstünlüklere sahip olarak firma değerini yükseltebilmesi için hangi konumda bulunması ve iş alanında faaliyet göstermesi, gibi konularda yapılan stratejik çalışmalardır.( Ülgen ve Mirze, 2013:220-221)

Kurumsal stratejiler işletmelerin, geleceğini planlamak, mevcut durumunun analizini yapmak ve rekabet gücünü arttırmak amaçlarını taşımaktadır. Bu üç konu da işletmelerin sürekliliği açısından ve rekabet üstünlüğü sağlaması açısından önemlidir. Temel kurumsal stratejiler Tablo 2'de sunulmuştur.

Tablo 2. Kurumsal Strateji Çeşitleri

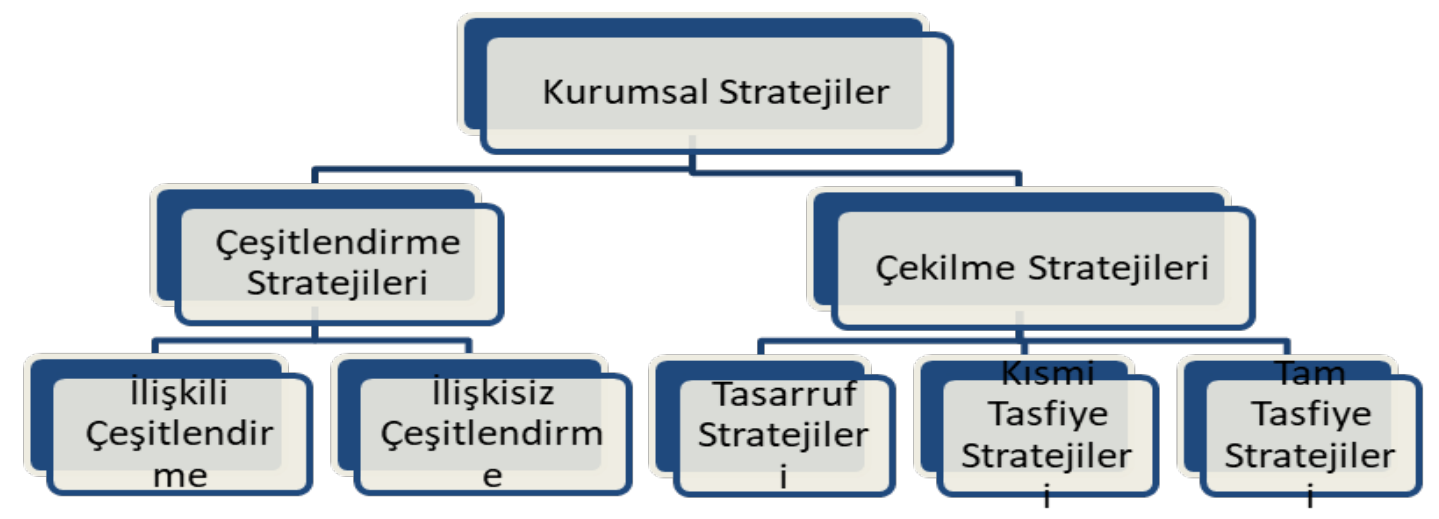

Kaynak: ÜLGEN, Hayri ve MIRZE (2013), Kadri, İsletmelerde Stratejik Yönetim, Beta Yayınlarl, İstanbul, ss. 222-233.

Çeşitlendirme stratejileri, yeni iş alanlarına girmek ve oradaki firsatlardan faydalanarak ortalamanın üzerinde getiri elde etmek isteyen işletmeler için uygulanan büyüme stratejisidir. İşletmelerin unsurlarında sayısal olarak bir artışa neden olmaktadır. İşletme, 
faaliyette bulunduğu mevcut iş alanları içerisinde veya benzer konularda yeni işlere girişmiş ise, ilişkili çeşitlendirme söz konusudur. İlişkili çeşitlendirme, işletmenin mevcut faaliyetlerinden ortak olarak yararlanmak, Pazar gücü elde etmek, varlık ve temel yeteneklerin yeni ürün ve işlerde kullanılarak ek gelir ve yarar sağlanması, maliyet tasarrufu sağlayarak yüksek getiri sağlamak, teşviklerden yararlanmak, riskleri azaltmak ve dağıtmak ve yöneticilere ek gelir sağlamak amaçlarıyla yapılabilmektedir. (Ülgen ve Mirze, 2013:222). $\mathrm{Bu}$ noktada çeşitlendirme stratejileri, yıldız ve sağmal nakit ineklerindeki SİB'ler için uygulanabilecek en iyi büyüme stratejileri olarak kabul edilebilecektir. Yıldızların, pazar payı ve pazar büyüme oranı yüksek olduğu için, mevcut pazar payını daha da arttırmak ve yoğun rekabet koşullarında güçlenebilmek üzere ilişkili çeşitlendirme stratejilerinden faydalanılabilecektir. Soru işaretinde yer alan SİB'ler için de pazar payını arttırmak üzere ilişkili çeşitlendirme stratejileri takip edilebilecektir. Fakat soru işaretindeki SİB'ler nakit yaratma kabiliyetine sahip olmadığı için, çeşitlendirme stratejilerinin uygulanabilmesinde, dışarıdan nakit desteğine ihtiyaç duyulacaktır. Eğer işletme, büyüme stratejisinde kararlı ise gerekli nakit diğer faaliyetlerden sağlanmalıdır.

Büyüme niyetinde olan işletmelerin daha önce faaliyette bulundukları alanlardan çok farklı ve değişik alanlarda yeni işlere girmesi ise ilişkisiz çeşitlendirme strateji olarak adlandırılmaktadır. İlişkisiz çeşitlendirme, finansal kaynakların sermaye piyasasında kullanılma arzusu, varlıkların ve temel yeteneklerin kullanılması yolu ile yarar sağlamak, teşviklerden yararlanmak, zorunlu el koyma nedenleri, başarısız işletmeleri yeniden yapılandırarak yüksek getiri elde etme arzusu ve yöneticilere ek getiri sağlamak amaçları ile yap1labilmektedir. (Ülgen ve Mirze, 2013:223-224).

İşletmeler her zaman arzu ettikleri hedeflere ulaşamayabilmektedir. Faaliyet gösterdikleri pazarlarda rekabet üstünlüğü sağlanamamış olabilmektedir. İşletme bu durumun devam edeceği hususunda öngörüsüne dayanarak, faaliyette bulunduğu işlerden bir kısmından veya tamamından vazgeçme yoluna gidebilecektir. İşletmelerin mevcut işlerin bir kısmından veya tamamından vazgeçmesi üzerine geliştirdikleri üst yönetim stratejilerine geri çekilme stratejileri adı verilmektedir. Bu stratejiler, tasarruf, kısmi tasfiye ve tam tasfiye stratejileridir. Tasarruf stratejileri, mevcut kötü durumun geçici ve düzeltilebilir olduğu düşüncesi ile iç verimliliği iyileştirmeye yönelik faaliyetlerdir. Kısmi tasfiye ve tam tasfiyede ise, faaliyetin devam ettirilmesi ileride daha da önemli sorunlara neden olabilecektir ve bu nedenle durdurulması işletmenin yararınadır. (Ülgen ve Mirze, 2013:230-232). Eğer ki soru işaretleri için çekilme politikası benimsenmiş ise, tasarruf stratejisi uygun olabilecektir. Fakat uyuz köpekler için en doğru strateji kısmi tasfiye veya tam tasfiyedir.

\subsection{Pazarlama Kararlarında Matrisin Yorumlanması}

Rekabetçi avantaja nasıl ulaşılacağı ve her bir firmanın bir endüstri içindeki bağıl konumunu nasıl yaygınlaştıracağı konusunu açıklamak için Porter, "jenerik stratejiler" adını verdiği belirli modeller takip eden strateji kategorilerini geliştirmiştir. (Collis ve Montgomery, 1997: 54). Porter, stratejiyi rekabetçi güçlere karşı savunma inşa etmek veya rekabetçi güçlerin oldukça zayıf olduğu endüstride uygun bir konum bulmak olarak görmektedir. Farklılaştırma ve maliyet liderliği, firmanın yeteneklerinin faaliyetleri rakiplerinden daha düşük maliyetlerde yürütmesi veya rakiplerle karşılaştırıldığında müşterinin zihninde farklılaşmaya neden olan faaliyetleri yapması anlamına gelecek şekilde, rekabetçi avantaj kazanmak için iki ana stratejidir. Stratejik konumlandırma, belli faaliyetleri belli bir şekilde 
yapma stratejisidir. Özetle, Porter'a göre, stratejinin esası, faaliyetleri rakiplerinden farklı bir şekilde yapmayı seçmek veya rakiplerden farklı faaliyetler yapmaktır. (Baraldi ve Brennan,v.diğerleri ,2007:883 ). Üçüncü strateji olan odaklanma ise, maliyet odağı ve farklılaştırma odağı olmak üzere ikiye ayrılmaktadır.

Maliyet liderliği, verimli ölçekte faal tesislerin kurulmasını, deneyimlerden güçlü maliyet düşüşlerinin elde edilmesini, maliyet ve genel giderlerin dikkatli kontrolünü, küçük müşteri hesaplarından kaçınılmasını, araştırma-geliştirme, servis, satış gücü, reklamlar vb. gibi alanlarda maliyetlerin en aza indirilmesini gerektirir (Porter, 2000:44) .Firmanın başarılı düşük maliyet stratejisini, karşılaştırılabilir ürünleri rakiplerinden daha verimli tasarım, üretme ve pazarlama yeteneğine sahip olma yeteneği ile açıklamaktadırlar.

Porter'a göre ikinci genel strateji, firmanın ürün ya da hizmetini farklılaştırarak, tüm sektörde benzersiz olarak görülen bir şey yaratmaktır ve gerçekleştirilebilmesi halinde, sektörde ortalamanın üzerinde getiriler elde etmek için uygulanabilir bir stratejidir. Müşterilerin marka sadakati ve bunun sonucunda fiyatlar karşısında oluşan daha düşük hassasiyeti nedeniyle farklılaştırma, rekabet hamlesine karşı bir güç sağlar. (Porter, 2000:47).

Son genel strateji olan odaklanma; hedef bir alıcı grubu, ürün yelpazesinin belli bir kısmı veya coğrafi bir pazar üzerinde yoğunlaşmadır. Farklılaştırmada olduğu gibi odaklanmada da birçok biçim olabilmektedir. Maliyet liderliği ve farklılaştırma stratejileri hedeflerini tüm sektör çapında gerçekleştirmeyi amaçlamasına rağmen, odaklanma stratejisi belirli bir hedefe çok iyi bir şekilde hizmet vermek üzerine kurulur ve her bir işlevsel politika bu ilke göz önünde tutularak geliştirilir. Öte yandan işletmeler, odaklanma stratejisi ile ya belirli bir hedefin ihtiyaçlarını daha iyi karşılayarak farklılaştırmayı ya da bu hedefe hizmet vermekle maliyetlerini düşürerek maliyet liderliğine ulaşmayı, ya da bunların her ikisini birden gerçekleştirebilme olanağı bulmaktadır. Odaklanmayı gerçekleştiren işletme, potansiyel olarak endüstri ortalamasının üzerinde getiriler de elde edebilmektedir. Odaklanma stratejisi her zaman, ulaşılabilir toplam Pazar payını kısıtladığı gibi, kârlılıktan ve satış hacminden ödün verilmesini gerektirmektedir. Ayrıca farklılaştırma stratejisi gibi odaklanma da toplam maliyet konumundan ödün vermeyi gerektirebilmektedir. (Porter, 2000:48-50).

BDG portföy matrisinin oluşturulması süreci aynı olmasına rağmen yorumlama ve strateji belirleme yöntemi, pazarlamada farklılaşmaktadır. Portföy matrisi oluşturulduktan sonra belirlenebilecek stratejiler Tablo 3’teki gibidir.

Tablo 3. Matristeki SİB veya Ürünler İçin Pazarlama Stratejileri

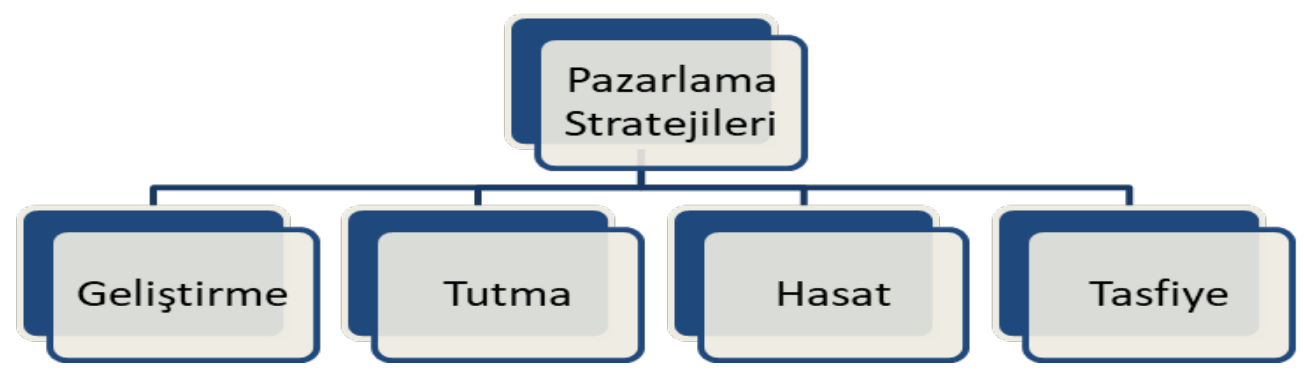

Kaynak: KOTLER, Philip (1997), Marketing Management, Analysis, Planning, Implementation, and Control, Ninth Edition, Prentice Hall, Inc., s. 173. 
Geliştirme stratejileri soru işaretleri için uygundur. Tutma stratejisi, sağmal nakit inekleri için uygundur. Hasat stratejisi, geleceği parlak olmayan sağmal nakit inekler için uygundur. Tasfiye stratejisi ise, nakit aktarılması istenmeyen soru işaretleri ile uyuz köpekler için uygun stratejidir. (Yükselen, 2010:61)

\section{YÖNETIM MUHASEBESİNDE BDG MATRİSI}

Yönetim muhasebesi, "işletme yöneticilerine, işletme yönetiminde alacaklart kararlarda ihtiyaç duydukları bilgi ve raporları düzenleyen, yorumlayan, yıllık bütçe ve standart uygulamaları ile kontrol sağlayan muhasebe türü" olarak tanımlanabilmektedir. Yönetim muhasebesinin temel fonksiyonları arasında planlama, performans değerlendirme ve kararların gelecekteki etkilerinin önemini belirleme yer almaktadır. (Yükçü,2011:20-21) Bu nedenle karar alma ve kontrol sağlamaya yönelik çeşitli yöntemler geliştirilmektedir. İlerleyen bölümlerde, BDG Portföy Matrisi'nin, yönetim muhasebesinde uygulanabilir bir yöntem olup olmadığı incelenmektedir. Genel olarak BDG portföy matrisinin oluşturulması aşağıdaki süreçleri içermektedir:

a) Ürünlerin veya stratejik iş birimlerinin belirlenmesi

b) Ürünlerin veya stratejik iş birimlerinin göreceli pazar paylarının ve pazar büyüme hılarının belirlenmesi ve matrise yerleştirilmesi

c) Göreceli pazar payının ve pazar büyüme hızının matris üzerindeki orta noktalarının belirlenmesi

d) Matrisin yorumlanmas1

Yönetim muhasebesinde matrisin oluşturulması aşaması için de benzer bir süreç gerekecektir. BDG Portföy matrisi analizinin temel amacı, işletmenin SİB'leri ve ürünlerinin, piyasadaki pazar payı ve pazarın büyüme hızı dikkate alındığındaki durumunun incelenmesidir. Yönetim muhasebesinde, BDG matrisinin uygulanması durumunda, işletmenin ürettiği ürünlerin tümünün dikkate alınması ve en büyük çerçevenin işletme olduğu varsayımı ile hareket edilmesi gerekmektedir. BDG portföy matrisinde, farklı SİB'ler ve ürünler dikkate alındığı için, işletmenin farklı tür ve çeşitteki mamulleri analiz için uygun olacaktır. İş birimleri mamuller olarak belirlenebileceği gibi, belirli mamul grupları olarak ta belirlenebilecektir. Örneğin, temizlik malzemeleri üreten bir işletme, iş birimlerini sabun, deterjan, çamaşır suyu, kova, bez çeşitleri şeklinde belirleyebildiği gibi, sabun, deterjan ve çamaşır suyunun oluşturduğu kimyasallar ve kova, bez çeşitlerinin oluşturduğu malzemeler olarak da belirleyebilecektir. Mamullerin veya iş birimlerinin göreceli pazar paylarının ve pazar büyüme hızlarının belirlenmesi ve matrise yerleştirilmesi, en geniş çerçevenin işletme olduğu varsayımı altında yapılmalıdır. Bu nedenle rakip firmaların bilgisi yerine, işletmenin mamullerinin detaylı maliyet bilgisine ihtiyaç duyulacaktır.

Matrisin dikey ekseninde, işletmenin satışlarının büyüme hızı yer almalıdır. Satışlarının büyüme hızı, üretilen mamuller olarak ele alınmalıdır. Satışların büyüme hızının konjonktürel dalgalanmalardan etkilenmemesi için son birkaç senenin ortalaması şeklinde hesaplanması, daha sağlıklı sonuçlanacaktır. Satışların büyüme hızı aşağıdaki formül yardımı ile hesaplanabilmektedir. 


$$
\begin{aligned}
& \text { Satışlann Büyüme } \\
& \text { Hız }
\end{aligned}=\frac{\text { Dönemin Satışları- Önceki Yıl Satışları }}{\text { Geçmiş Yıl Satışları }}
$$

Pazarlama ve stratejik yönetimdeki BDG portföy matrisinden farklı olarak, yönetim muhasebesinde yatay eksende, mamullerin katkı marjları yer almalıdır. Çünkü daha önceden de belirtildiği gibi, yönetim muhasebesindeki amaç işletme kârlılığını maksimize edecek şekilde maliyet ve yönetim kararları vermektir. Dolayısı ile, mamullerin rakiplerine göre göreceli pazar payı yerine, işletmeye sağladığı katkı ile hesaplanacak "katkı marjı"nın dikkate alınması yerinde olacaktır. Mamul Katkı marjı aşağıdaki formül ile hesaplanabilmektedir.

Katkı Marjı $=\frac{\begin{array}{l}\text { Mamul Toplam } \\ \text { Satış Hasılatı }\end{array}-\begin{array}{l}\text { Mamul Toplam } \\ \text { Değişken Giderler }\end{array}}{\text { Mamuı Toplam Satı̧ Hasılatı }}$

Matriste mamullerin satış büyüme hızları ve kâr marjlarının yanı sıra, yatay ve dikey eksenlerin orta noktalarının da hesaplanması gerekmektedir. Kâr marjı ekseninin orta noktası, "ortalama katkı marjı", aşağıdaki gibi hesaplanacaktır.

$$
\begin{aligned}
& \text { Ortalama Katkı } \\
& \text { Marjı }
\end{aligned}=\frac{\text { Toplam Katkı }}{\text { Toplam Satı̧ Hasılatı }}
$$

Satışların büyüme hızının orta noktası ise (eşik değeri olarak da adlandırılabilecektir) aşağıdaki formül yardımı ile hesaplanabilecektir.

$$
\begin{aligned}
& \text { Satış ların Büyüme } \\
& \text { Hızı Eşik Noktası }
\end{aligned}=\frac{\text { Toplam Satışların Büyüme Hızı }}{\text { Mamul Sayısı (n) }}
$$

Her mamul için toplam katkı marjları ve satışlarının büyüme hızları hesaplandıktan sonra bulunan değerler matrise yerleştirilmelidir. Sonrasında, mamullerin matristeki konumuna göre analizleri yapılabilecektir. Yönetim muhasebesinde BDG portföy matrisi Tablo 4'teki gibi olacaktır.

Tablo 4. Yönetim Muhasebesinde BDG Portföy Matrisi

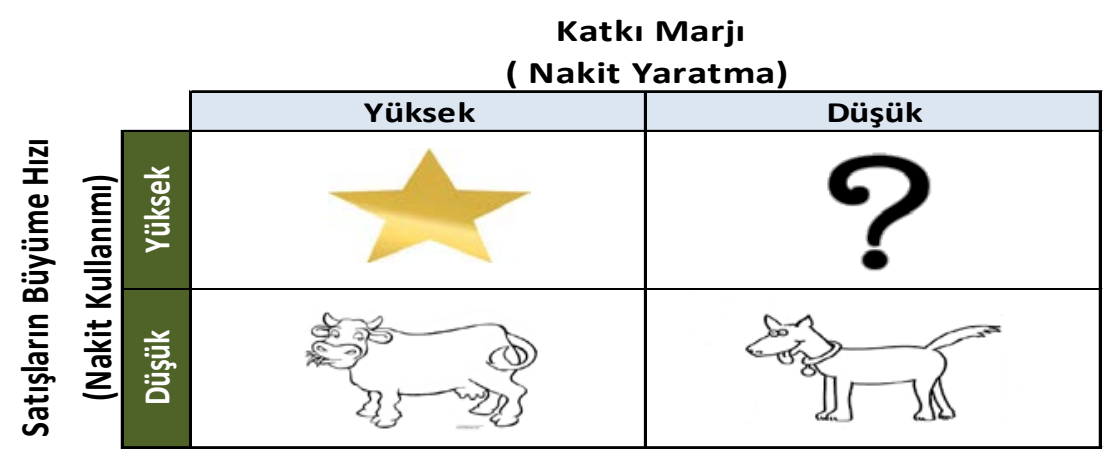


İşletmedeki mamuller, satışların büyüme hızına ve kâr marjına göre matrisin yıldızlar, soru işaretleri, sağmal nakit inekleri ve uyuz köpeklerden birinde yer alacaktır. Bu bölümlendirmeler genel olarak stratejik yönetimdeki yorumlamalar ile örtüşmektedir. Yıldızlarda yer alan mamuller, satışlarının büyüme hızı ve katkı marjlarının yüksek olması sebebi ile işletmeye yüksek nakit girişi sağlamaktadırlar. Fakat yıldızlar aynı zamanda, satış büyüme hızlarının yüksek olması sebebiyle, kapasite artırımı ihtiyacına neden olabilecektir. $\mathrm{Bu}$ durumda daha fazla nakit kullanımı gerekmektedir. Sağmal nakit inekleri, satışların büyüme hızının düşük olması sebebiyle, nakit kullanımı ihtiyacı yaratmamaktadır. Buna rağmen katkı marjının yüksek olması sebebiyle, işletmeye yüksek miktarda nakit sağlamaktadır. $\mathrm{Bu}$ nakit, işletmenin olağan faaliyetleri ve matrisin diğer bölümlerindeki mamullerin nakit ihtiyaçlarını sağlaması açısından önemlidir. Sağmal nakit inekleri, diğer bir deyişle, işletmenin devamlılı̆̆ını sağlamasındaki en önemli finansördür. Soru işaretlerindeki mamuller ise, geleceğinin ne olacağ 1 hakkında önemli belirsizlik taşıyan mamullerdir. Katk1 marjının düşük olması sebebiyle, değişken maliyetlerinin kontrol altında tutulması gerekmektedir. Satışların büyüme hızı dikkate alınarak, kaliteden ödün vermeyecek şekilde, değişken maliyetlerin düşürülmeye çalışılması gerekmektedir. Fakat bu durum oldukça risklidir. Çünkü, bu çalışma neticesinde söz konusu mamulün satışlarının düşmesi söz konusu olabilecektir ve mamul, uyuz köpekler bölümüne kayabilecektir. Uyuz köpekler ise, düşük katkı marjı ve satış büyüme hızları ile işletmenin üretimine son vermesi gereken mamullerdir. Bazı durumlarda bu mamuller, işletmenin itibar sebebiyle üretimine devam ettiği mamuller olabilmektedir. Böyle durumlarda da, farklı satış alanlarına yönelme ve diğer pazarlama stratejileri geliştirme, ürün iyileştirme gibi çalışmalar ile satışlarının artırılabilmesi üzerine çalış1labilecektir. Stratejik yönetim ve pazarlamadaki BDG portföy matrisinin amacı ve özellikleri ile yönetim muhasebesinde BDG portföy matrisinin amacı ve diğer özellikleri Tablo 5'te sunulmuştur.

Tablo 5. Stratejik Yönetim/Pazarlama BDG Portföy Matrisi ve Yönetim Muhasebesi BDG Portföy Matrisi Karşılaştırması

\begin{tabular}{|c|c|}
\hline $\begin{array}{l}\text { STRATEJIK YÖNETIMM VE PAZARLAMADA } \\
\text { BDG MATRİII }\end{array}$ & $\begin{array}{l}\text { YÖNETIMM MUHASEBESINDE BDG } \\
\text { MATRİSI }\end{array}$ \\
\hline $\begin{array}{l}\text { AMAC: İşletmelerin uzun dönemde rekabet üstünlüğü sağlayabilmesi } \\
\text { ve sürekliliğini sağlayabilmesi için hangi iş alanlarında, hangi konumda } \\
\text { faaliyet göstermesi gerektiğini belirlemek. }\end{array}$ & $\begin{array}{l}\text { AMACC: İşletmenin ürettiği mevcut mamullerin etkinliğinin } \\
\text { analizini ve üretilecek mamullerin planlamasını yapmak ve } \\
\text { de işletmenin karını maksimize edecek şekilde kararlar } \\
\text { almak. }\end{array}$ \\
\hline CEVAP ARANAN SORULAR: & CEVAP ARANAN SORULAR: \\
\hline a) Gelecekte hangi iş alanında, hangi işler & a) Gelecekte işletme hangi ürünleri üretmelidir? \\
\hline $\begin{array}{l}\text { b) Mevcut iş alanlarındaki etkinlikleri ve işler sürdürülmeli midir, } \\
\text { arttırılmalı mıdır? }\end{array}$ & $\begin{array}{l}\text { b) Mevcut mamullerin etkinlikleri ve üretimi sürdürülmeli } \\
\text { midir, arttırılmalı mıdır? }\end{array}$ \\
\hline $\begin{array}{l}\text { c) Yoksa kısmen veya tamamen terk edip yeni iş alanlarına mı } \\
\text { girilmelidir? }\end{array}$ & $\begin{array}{l}\text { c) Yoksa üretim mikarı kısılmalı veya üretimine tamamen } \\
\text { son mu verilmelidir? }\end{array}$ \\
\hline $\begin{array}{l}\text { d) İşletme mevcut işlerinde rekabet edebilmek için ne tür stratejiler } \\
\text { geliştirmelidir ve mevcut iş nasıl büyütülebilir? }\end{array}$ & $\begin{array}{l}\text { d) İşletme mevcut hasilatını ve karını nasıl arttırabilir, ne } \\
\text { tür stratejiler geliştirmelidir? }\end{array}$ \\
\hline \begin{tabular}{|l} 
ANALIZ İÇİN GEREKEN KOŞULLAR: \\
\end{tabular} & ANALIZ İÇIN GEREKEN KOȘULLAR: \\
\hline $\begin{array}{l}\text { a) Birden fazla stratejik iş birimi veya ürün mevcut olmalıdır. } \\
\text { b) Pazardaki rakiplerin verilerine ulaşabilinmelidir. }\end{array}$ & $\begin{array}{l}\text { a) Birden fazla ürün üretilmelidir. } \\
\text { b) Maliyet muhasebesinin, katkı marjının } \\
\text { hesaplanabilmesine imkan verecek şekilde etkin olması } \\
\text { gerekmektedir. } \\
\text { c) Birim maliyetlerin, satış fiyatlarının ve miktarlarının } \\
\text { birbirine çok yakın olduğu mamul portföylerinin analizi çok } \\
\text { sağlıklı sonuçlar vermeyecektir. }\end{array}$ \\
\hline
\end{tabular}


Yönetim Muhasebesinde BDG Portföy Matrisine, amacı ve özellikleri doğrultusunda “BDG Mamul Portföy Matrisi” ismi verilebilecektir.

\section{UYGULAMA}

Çalışmanın bu bölümünde, bir üretim işletmesinde, BDG portföy matrisi analizi yapılacak ve değerlendirilecektir.

\section{1. İşletmenin Faaliyet Konusu ve Diğger Bilgiler}

ABC Kompozit Teknolojileri Sanayi ve Ticaret A.Ş., yirmi yılı aşkın bir süredir, yenilenebilir kompozit ürünleri üretmekte olan, özellikle inşaat sektörü dahil birçok alanda öncü rol üstlenmiş bir firmadır. Firmanın merkezi Amerika Birleşik Devletleri'nde olup, kendi geliştirdiği özgün ürün seçenekleri ve yeni projeler ile oluşturduğu uluslararası stratejik ortaklıklarla, sonsuz ve kazançlı firsatlar sunan Orta Doğu, Afrika, Güney Amerika ve Karayipler pazarlarındaki artan toplu konut ve diğer inşaat ürünleri talebini karşılamak için çalışmalar yapmaktadır.

Söz konusu işletmenin Türkiye şubesine ait veriler üzerinde çalışılmıştır. İşletmenin etkin bir maliyet muhasebesi ve bütçeleme departmanı bulunmaktadır. Bu nedenle analiz için gerekli bilginin güvenilir olduğu söylenebilmektedir.

İşletmenin 2014 y1lı verilerinden faydalanılmıştır. İşletmede farklı işlevsel özelliklere sahip, farklı çeşitlerde, 200 adet mamul tanımlanmıştır. Fakat tanımlanmış olan mamullerin bir kısmının üretimine henüz başlanmamış, bir kısmının ise henüz satış1 gerçekleştirilmemiştir. Bu nedenle, söz konusu mamullerden 179 tanesi uygulamaya dahil edilmiştir. Bu mamullerin birim maliyetleri ve satış fiyatları rakamsal olarak yakın değerler almamaktadır. $\mathrm{Bu}$ nedenle BDG Mamul Portföy Analizi için "uygun" olarak kabul edilebilecektir.

\subsection{Mamullerin Katkı Marjlarının ve Satışların Büyüme Hızlarının Hesaplanması}

Mamullerin katkı marjı ve satışlarının büyüme hızı ile ilgili hesaplamalar Tablo 6'daki gibidir. 
Tablo 6. ABC Kompozit Teknolojileri Sanayi ve Ticaret A.Ş Mamullerin Katkı Marjları ve Satışların Büyüme Hızı Hesaplaması

\begin{tabular}{|c|c|c|c|c|c|c|c|c|c|c|}
\hline & & & Satış Hasılatı & \begin{tabular}{|l|} 
TOPLAM \\
Değişken \\
Maliyetler
\end{tabular} & $\begin{array}{l}\text { Toplam } \\
\text { Katkı }\end{array}$ & $\begin{array}{l}\text { Katkı } \\
\text { Marjı }\end{array}$ & $\begin{array}{l}2013 \\
\text { MiKTAR }\end{array}$ & $\begin{array}{l}2014 \\
\text { MiKTAR }\end{array}$ & \begin{tabular}{|l} 
Satışların \\
Büyüme \\
Hızı
\end{tabular} & $\begin{array}{r}\text { Birim Satış } \\
\text { Fiyatı }\end{array}$ \\
\hline & KOD-1 & KOD-4 & $6.426 .278,81$ & $4.454 .149,30$ & & & & 299605 & & \\
\hline NO & Formüllü & Formüllü & & & & & & & & \\
\hline 1 & M01RA00A0011 & 10 LUK MAHYA ADAPTÖRÜ & 320,00 & 200,41 & 119,59 & $37,37 \%$ & 2 & 10 & $400 \%$ & 32,00 \\
\hline 2 & M01RA00A0051 & 10 LUK MAKAS MERTEK ADAPTÖRÜ & $7.000,00$ & 930,32 & $6.069,68$ & $86,71 \%$ & 25 & 70 & $180 \%$ & 100,00 \\
\hline 3 & M01B000A0011 & 10 LUK PROFIL & $334.875,00$ & $233.895,76$ & $100.979,24$ & $30,15 \%$ & 7238 & 13395 & $85 \%$ & 25,00 \\
\hline 4 & M01B000A0011 & 10 LUK PROFIL & $17.025,00$ & $11.891,23$ & $5.133,77$ & $30,15 \%$ & 634 & 681 & $7 \%$ & 25,00 \\
\hline 5 & M01RA00A0141 & 10 LUK PROFIL ALTI & $61.217,00$ & $39.848,39$ & $21.368,61$ & $34,91 \%$ & 2324 & 3601 & $55 \%$ & 17,00 \\
\hline 6 & M01RA00A0141 & 10 LUK PROFIL ALTI & 288,00 & 199,19 & 88,81 & $30,84 \%$ & 3 & 18 & $500 \%$ & 16,00 \\
\hline 7 & M01RA00A0121 & 10 LUK PROFIL ÜSTÜ & $15.730,00$ & $12.015,96$ & $3.714,04$ & $23,61 \%$ & 324 & 1210 & $273 \%$ & 13,00 \\
\hline 8 & M01RA00A0121 & 10 LUK PROFIL ÜSTÜ & $1.712,00$ & $1.416,76$ & 295,24 & $17,25 \%$ & 28 & 143 & $410 \%$ & 12,00 \\
\hline 9 & M01W000A0191 & 10 LUK SAÇAK TUĞLASI & 360,00 & 263,73 & 96,27 & $26,74 \%$ & 10 & 24 & $140 \%$ & 15,00 \\
\hline 10 & M01W000A0051 & 10 LUK TUĞLA HF & 792,00 & 563,66 & 228,34 & $28,83 \%$ & 17 & 66 & $288 \%$ & 12,00 \\
\hline 11 & M01W000A0051 & 10 LUK TUĞLA HF & $22.632,00$ & $16.106,86$ & $6.525,14$ & $28,83 \%$ & 1224 & 1886 & $54 \%$ & 12,00 \\
\hline 12 & M01F000A0141 & 120x120 ZEMIN PARÇASI & $29.475,00$ & $24.565,96$ & $4.909,04$ & $16,65 \%$ & 41 & 131 & $220 \%$ & 225,00 \\
\hline 13 & M01S000A0011 & 120x30 MERDIVEN & 730,00 & 521,57 & 208,43 & $28,55 \%$ & 7 & 10 & $43 \%$ & 73,00 \\
\hline 14 & M01S000A0021 & 120x40 MERDIVEN & $4.740,00$ & $3.486,56$ & $1.253,44$ & $26,44 \%$ & 28 & 79 & $182 \%$ & 60,00 \\
\hline 15 & M01W000A0183 & 120x60 PANEL TUĞLA FDR & 56,00 & 47,25 & 8,75 & $15,63 \%$ & 2 & 2 & $0 \%$ & 28,00 \\
\hline 16 & M01FA00A0061 & 13 LÜK ARAKAT KAMA & $6.328,00$ & $4.283,16$ & $2.044,84$ & $32,31 \%$ & 328 & 452 & $38 \%$ & 14,00 \\
\hline 17 & M01W000A0411 & 160 LIK LENTO TUĞLASI & $2.030,00$ & $1.678,05$ & 351,95 & $17,34 \%$ & 56 & 58 & $4 \%$ & 35,00 \\
\hline 18 & M01FA00A0071 & 20 LIK ARAKAT KAMA & $9.860,00$ & $6.311,98$ & $3.548,02$ & $35,98 \%$ & 213 & 580 & $172 \%$ & 17,00 \\
\hline 19 & M01W000A0061 & 20 LIK TUĞLA HF & $120.744,00$ & $91.158,22$ & $29.585,78$ & $24,50 \%$ & 7423 & 9288 & $25 \%$ & 13,00 \\
\hline 20 & M01W000A0061 & 20 LIK TUĞLA HF & $47.125,00$ & $35.578,02$ & $11.546,98$ & $24,50 \%$ & 2745 & 3625 & $32 \%$ & 13,00 \\
\hline 21 & M01W000A0081 & 20 LIK YARIM TUĞLA & $321.852,00$ & $235.271,80$ & $86.580,20$ & $26,90 \%$ & 25000 & 26821 & $7 \%$ & 12,00 \\
\hline 22 & M01W000A0081 & 20 LIK YARIM TUĞLA & $1.800,00$ & $1.315,79$ & 484,21 & $26,90 \%$ & 98 & 150 & $53 \%$ & 12,00 \\
\hline 23 & M01W000A0091 & 20 LIK YARIM TUĞLA HF & $27.450,50$ & $20.275,00$ & $7.175,50$ & $26,14 \%$ & 1425 & 2387 & $68 \%$ & 11,50 \\
\hline 24 & M01F000A0051 & 20 LIK ZEMIN TUĞLASI ETEKSIZ & 621,00 & 451,51 & 169,49 & $27,29 \%$ & 13 & 54 & $315 \%$ & 11,50 \\
\hline 25 & M01F000A0091 & 20 LiK ZEMIN TUĞLASI h:10cm & $30.397,25$ & $23.472,17$ & $6.925,08$ & $22,78 \%$ & 1421 & 2587 & $82 \%$ & 11,75 \\
\hline 26 & M01W000A0161 & $20 \times 5.8$ TUĞLA & $24.369,50$ & $16.751,12$ & $7.618,38$ & $31,26 \%$ & 1326 & 2074 & $56 \%$ & 11,75 \\
\hline 27 & M01RA00A0081 & 3 KANALLI ADAPTÖR & 282,00 & 196,85 & 85,15 & $30,20 \%$ & 13 & 24 & $85 \%$ & 11,75 \\
\hline 28 & M01W000A0211 & 30 LUK KÖŞE TUĞLA & $30.380,00$ & $24.279,06$ & $6.100,94$ & $20,08 \%$ & 985 & 1736 & $76 \%$ & 17,50 \\
\hline 29 & M01W000A0211 & 30 LUK KÖŞE TUĞLA & $42.157,50$ & $33.691,35$ & $8.466,15$ & $20,08 \%$ & 1127 & 2409 & $114 \%$ & 17,50 \\
\hline 30 & M01F000A0111 & 30 LUK KÖŞE ZEMIN TUĞLASI h:10cm & $58.971,75$ & $43.867,34$ & $15.104,41$ & $25,61 \%$ & 3821 & 3867 & $1 \%$ & 15,25 \\
\hline 31 & M01F000A0111 & 30 LUK KÖŞE ZEMIN TUĞLASI h:10cm & $9.836,25$ & $7.316,90$ & $2.519,35$ & $25,61 \%$ & 234 & 645 & $176 \%$ & 15,25 \\
\hline 32 & M015000A0031 & 30 LUK MERDIVEN KENAR TUĞLASI & $1.120,00$ & 881,24 & 238,76 & $21,32 \%$ & 27 & 80 & $196 \%$ & 14,00 \\
\hline 33 & M01W000A0071 & 30 LUK TUĞLA & $153.594,00$ & $122.930,32$ & $30.663,68$ & $19,96 \%$ & 9567 & 10971 & $15 \%$ & 14,00 \\
\hline 34 & M01W000A0071 & 30 LUK TUĞLA & $49.588,00$ & $39.688,21$ & $9.899,79$ & $19,96 \%$ & 2568 & 3542 & $38 \%$ & 14,00 \\
\hline 35 & M01F000A0061 & 30 LUK ZEMIN TUĞLASI ETEKSIZ & $2.887,50$ & $2.146,03$ & 741,47 & $25,68 \%$ & 128 & 231 & $80 \%$ & 12,50 \\
\hline 36 & M04WI00A0051 & 30×30 GÖRME ENGELLI KILAVUZ YOLU & 250,00 & 185,42 & 64,58 & $25,83 \%$ & 17 & 20 & $18 \%$ & 12,50 \\
\hline 37 & M04W100A0061 & $30 \times 30$ GÖRME ENGELLI UYARI YOLU & 250,00 & 180,44 & 69,56 & $27,82 \%$ & 18 & 20 & $11 \%$ & 12,50 \\
\hline 38 & M01F000A0121 & 30x30 ZEMIN PARÇASI & $48.472,00$ & $38.774,47$ & $9.697,53$ & $20,01 \%$ & 1865 & 2656 & $42 \%$ & 18,25 \\
\hline 39 & M02DC10A0101 & 39x42 MAZGAL TAKIM D400 & 37,00 & 29,13 & 7,87 & $21,26 \%$ & 1 & 1 & $0 \%$ & 37,00 \\
\hline 40 & M01W000A0031 & 40 LIK TUĞLA & $166.652,50$ & $119.945,26$ & $46.707,24$ & $28,03 \%$ & 7888 & 9523 & $21 \%$ & 17,50 \\
\hline 41 & M01W000A0031 & 40 LIK TUĞLA & $87.045,00$ & $62.649,15$ & $24.395,85$ & $28,03 \%$ & 3268 & 4974 & $52 \%$ & 17,50 \\
\hline 42 & M01F000A0081 & 40 LIK ZEMIN TUĞLASI h:10cm & $152.418,00$ & $120.727,34$ & $31.690,66$ & $20,79 \%$ & 9867 & 10887 & $10 \%$ & 14,00 \\
\hline 43 & M04WI00A0031 & 40×40 GÖRME ENGEயU KALDIRIM KILAVUZ YOLU & 170,00 & 124,51 & 45,49 & $26,76 \%$ & 7 & 10 & $43 \%$ & 17,00 \\
\hline 44 & M04WIO0A0041 & 40X40 GÖRME ENGELU KALDIRIM UYARI YOLU & 300,00 & 236,98 & 63,02 & $21,01 \%$ & 11 & 20 & $82 \%$ & 15,00 \\
\hline 45 & M04WIOOA0011 & 40×40 GÖRME ENGELLI KILAVUZ YOLU & 165,00 & 127,68 & 37,32 & $22,62 \%$ & 9 & 11 & $22 \%$ & 15,00 \\
\hline 46 & M04WIOOA0011 & 40×40 GÖRME ENGELLI KILAVUZ YOLU & $7.650,00$ & $5.931,06$ & $1.718,94$ & $22,47 \%$ & 452 & 510 & $13 \%$ & 15,00 \\
\hline 47 & M04WI00A0021 & 40×40 GÖRME ENGELLI UYARI YOLU & 165,00 & 121,06 & 43,94 & $26,63 \%$ & 5 & 11 & $120 \%$ & 15,00 \\
\hline 48 & M04W100A0021 & 40×40 GÖRME ENGELLI UYARI YOLU & $3.750,00$ & $2.756,24$ & 993,76 & $26,50 \%$ & 230 & 250 & $9 \%$ & 15,00 \\
\hline 49 & M01W000A0171 & $40 \times 5.8$ TUĞLA & $27.040,00$ & $18.727,54$ & $8.312,46$ & $30,74 \%$ & 1235 & 2080 & $68 \%$ & 13,00 \\
\hline 50 & M02DC10A0041 & 48x48 MAZGAL TAKIM D400 & $10.695,00$ & $6.898,43$ & $3.796,57$ & $35,50 \%$ & 74 & 93 & $26 \%$ & 115,00 \\
\hline 51 & M01W000A0241 & 50 LIK ORTA TUĞLA & $99.286,00$ & $75.666,04$ & $23.619,96$ & $23,79 \%$ & 3869 & 4513 & $17 \%$ & 22,00 \\
\hline 52 & M01W000A0241 & 50 LIK ORTA TUĞLA & $49.104,00$ & $37.422,20$ & $11.681,80$ & $23,79 \%$ & 1563 & 2232 & $43 \%$ & 22,00 \\
\hline 53 & M01W000A0121 & 50 LiK TUĞLA & $48.960,00$ & $38.986,36$ & $9.973,64$ & $20,37 \%$ & 2700 & 2720 & $1 \%$ & 18,00 \\
\hline 54 & M01W000A0121 & 50 LiK TUĞLA & $53.850,61$ & $42.880,71$ & $10.969,89$ & $20,37 \%$ & 1985 & 2992 & $51 \%$ & 18,00 \\
\hline 55 & M01RA00A0021 & 6 LIK MAHYA ADAPTÖRÜ & 91,50 & 66,09 & 25,41 & $27,77 \%$ & 2 & 6 & $200 \%$ & 15,25 \\
\hline 56 & M01RA00A0061 & 6 LIK MAKAS MERTEK ADAPTÖRÜ & 624,00 & 445,93 & 178,07 & $28,54 \%$ & 24 & 48 & $100 \%$ & 13,00 \\
\hline
\end{tabular}


The Journal of Accounting and Finance- August 2019 Special Issue 527-544

\begin{tabular}{|c|c|c|c|c|c|c|c|c|c|c|}
\hline 57 & M01B000A0021 & 6 LIK PROFIL & $49.115,00$ & $34.954,94$ & $14.160,06$ & $28,83 \%$ & 2536 & 2585 & $2 \%$ & 19,00 \\
\hline 58 & M01B000A0021 & 6 LIK PROFIL & $3.819,00$ & $2.717,97$ & $1.101,03$ & $28,83 \%$ & 162 & 201 & $24 \%$ & 19,00 \\
\hline 59 & M01B000A0021 & 6 LIK PROFIL & $3.097,00$ & $2.204,12$ & 892,88 & $28,83 \%$ & 83 & 163 & $96 \%$ & 19,00 \\
\hline 60 & M01RA00A0151 & 6 LIK PROFIL ALTI & 281,75 & 204,51 & 77,24 & $27,41 \%$ & 8 & 23 & $188 \%$ & 12,25 \\
\hline 61 & M01RA00A0131 & 6 LIK PROFIL ÜSTÜ & 404,25 & 289,05 & 115,20 & $28,50 \%$ & 18 & 33 & $83 \%$ & 12,25 \\
\hline 62 & M01RA00A0041 & 6 LIK SAÇAK ADAPTÖRÜ & 360,00 & 264,38 & 95,62 & $26,56 \%$ & 10 & 24 & $140 \%$ & 15,00 \\
\hline 63 & M01W000A0421 & 6 LIK SAÇAK TUĞLASI D:20 cm & 585,00 & 446,96 & 138,04 & $23,60 \%$ & 13 & 39 & $200 \%$ & 15,00 \\
\hline 64 & M01F000A0071 & 60 LIK ZEMIN TUĞLASI ETEKSIZ & 30,00 & 22,56 & 7,44 & $24,81 \%$ & 1 & 2 & $100 \%$ & 15,00 \\
\hline 65 & M02MHC1A0091 & 60×80 TELEKOM TAKIM B125 & 93,00 & 71,68 & 21,32 & $22,92 \%$ & 1 & 1 & $0 \%$ & 93,00 \\
\hline 66 & M01F000A0131 & 75x100 ZEMIN PARÇASI & $253.890,00$ & $170.189,54$ & $83.700,46$ & $32,97 \%$ & 3248 & 4095 & $26 \%$ & 62,00 \\
\hline 67 & M01F000A0131 & 75x100 ZEMIN PARÇASI & $72.540,00$ & $48.625,58$ & $23.914,42$ & $32,97 \%$ & 703 & 1170 & $66 \%$ & 62,00 \\
\hline 68 & M01W000A0231 & 80 LIK KÖŞE TUĞLA & $178.959,50$ & $121.969,10$ & $56.990,40$ & $31,85 \%$ & 3308 & 4903 & $48 \%$ & 36,50 \\
\hline 69 & M01W000A0231 & 80 LIK KÖŞE TUĞLA & $32.010,50$ & $21.816,63$ & $10.193,87$ & $31,85 \%$ & 740 & 877 & $19 \%$ & 36,50 \\
\hline 70 & M01W000A0251 & 90 LIK ORTA TUĞLA & $145.882,00$ & $93.721,61$ & $52.160,39$ & $35,76 \%$ & 3214 & 3839 & $19 \%$ & 38,00 \\
\hline 71 & M01W000A0251 & 90 LIK ORTA TUĞLA & $29.754,00$ & $19.115,39$ & $10.638,61$ & $35,76 \%$ & 723 & 783 & $8 \%$ & 38,00 \\
\hline 72 & M01R000A0011 & BÜYÜK ÇATI KAPLAMASI & $650.880,00$ & $470.778,13$ & $180.101,87$ & $27,67 \%$ & 5560 & 9040 & $63 \%$ & 72,00 \\
\hline 73 & M02MHCAA0011 & ÇAP 69 ROGAR ÇERÇEVE YÜK. & 136,00 & 117,20 & 18,80 & $13,83 \%$ & 1 & 4 & $300 \%$ & 34,00 \\
\hline 74 & M02MHC1A0011 & ÇAP 69 ROGAR TAKIM D400 & $21.780,00$ & $14.888,78$ & $6.891,22$ & $31,64 \%$ & 93 & 121 & $30 \%$ & 180,00 \\
\hline 75 & M01RA00A0161 & ÇATI MAHYA KIREMITI & $34.694,00$ & $23.627,99$ & $11.066,01$ & $31,90 \%$ & 1425 & 1577 & $11 \%$ & 22,00 \\
\hline 76 & M05WW00A0021 & ÇERÇEVE KÖŞESi & 75,00 & 45,79 & 29,21 & $38,95 \%$ & 2 & 5 & $150 \%$ & 15,00 \\
\hline 77 & MO5WW00A0011 & ÇERÇEVE PROFILI & 17,00 & 10,66 & 6,34 & $37,27 \%$ & 1 & 1 & $0 \%$ & 17,00 \\
\hline 78 & M01W000A0261 & ÇIFT SIRA BAĞLANTI TUĞLASI & $3.247,00$ & $1.951,87$ & $1.295,13$ & $39,89 \%$ & 188 & 191 & $2 \%$ & 17,00 \\
\hline 79 & M04SBO0A0011 & D BANK AYAK & $4.368,00$ & $3.406,76$ & 961,24 & $22,01 \%$ & 63 & 84 & $33 \%$ & 52,00 \\
\hline 80 & M04SBO0A0021 & D BANK ÇITA & $6.509,00$ & $4.743,26$ & $1.765,74$ & $27,13 \%$ & 201 & 283 & $41 \%$ & 23,00 \\
\hline 81 & M04SB10A0011 & D BANK TAKIM & $1.295,00$ & 948,58 & 346,42 & $26,75 \%$ & 2 & 7 & $250 \%$ & 185,00 \\
\hline 82 & M04D000A0011 & DECK ÇIFTLi & $11.628,00$ & $10.914,66$ & 713,34 & $6,13 \%$ & 567 & 612 & $8 \%$ & 19,00 \\
\hline 83 & M04D000A0021 & DECK TEKLI & 32,00 & 28,28 & 3,72 & $11,63 \%$ & 2 & 2 & $0 \%$ & 16,00 \\
\hline 84 & M04D000A0021 & DECK TEKLI & $35.295,00$ & $32.489,13$ & $2.805,87$ & $7,95 \%$ & 1598 & 2353 & $47 \%$ & 15,00 \\
\hline 85 & M01WA01A0041 & DIŞ KÖŞE PANEL PROFILI & $1.305,00$ & 973,47 & 331,53 & $25,40 \%$ & 15 & 45 & $200 \%$ & 29,00 \\
\hline 86 & M04LBO0A0011 & DiREK TIPI ÇÖP KOVASI GÖVDE & $1.848,00$ & $1.378,90$ & 469,10 & $25,38 \%$ & 28 & 77 & $175 \%$ & 24,00 \\
\hline 87 & M04LBO0A0021 & DIREK TIPI ÇÖP KOVASI KAPAK & $1.232,00$ & 884,14 & 347,86 & $28,24 \%$ & 75 & 77 & $3 \%$ & 16,00 \\
\hline 88 & M04DA00A0011 & DÖŞEME RAY & $11.570,00$ & $7.767,41$ & $3.802,59$ & $32,87 \%$ & 705 & 890 & $26 \%$ & 13,00 \\
\hline 89 & M05ST00A0011 & DUŞ TEKNESI & 114,00 & 89,11 & 24,89 & $21,83 \%$ & 1 & 3 & $200 \%$ & 38,00 \\
\hline 90 & M05ST00A0021 & DUŞ TEKNESI AYAK & 144,00 & 69,23 & 74,77 & $51,93 \%$ & 7 & 9 & $29 \%$ & 16,00 \\
\hline 91 & M01RA00A0181 & KALKAN DUVAR KAPATMA & $2.048,00$ & $1.180,64$ & 867,36 & $42,35 \%$ & 52 & 64 & $23 \%$ & 32,00 \\
\hline 92 & M01RA00A0171 & KALKAN DUVAR MAHYA KAPATMA & 196,00 & 143,07 & 52,93 & $27,01 \%$ & 11 & 14 & $27 \%$ & 14,00 \\
\hline 93 & M01FA00A0051 & KAMA & $257.796,00$ & $206.128,64$ & $51.667,36$ & $20,04 \%$ & 23459 & 28644 & $22 \%$ & 9,00 \\
\hline 94 & M01BP00A0011 & KURŞUN GEÇíRMEZ PARÇA & 126,00 & 96,75 & 29,25 & $23,22 \%$ & 3 & 9 & $200 \%$ & 14,00 \\
\hline 95 & M01BP00A0021 & KURŞUN GEÇiRMEZ PARÇA DIŞLi & 91,00 & 71,54 & 19,46 & $21,39 \%$ & 4 & 7 & $75 \%$ & 13,00 \\
\hline 96 & M05L000A0011 & LAVABO & $1.512,00$ & 590,07 & 921,93 & $60,97 \%$ & 29 & 54 & $86 \%$ & 28,00 \\
\hline 97 & M01W000A0131 & LENTO TUĞLASI & 43,00 & 26,67 & 16,33 & $37,97 \%$ & 1 & 1 & $0 \%$ & 43,00 \\
\hline 98 & M01W000A0141 & LENTO TUĞLASI HF & $648.242,00$ & $357.168,06$ & $291.073,94$ & $44,90 \%$ & 13560 & 17059 & $26 \%$ & 38,00 \\
\hline 99 & M01W000A0141 & LENTO TUĞLASI HF & $358.454,00$ & $197.500,84$ & $160.953,16$ & $44,90 \%$ & 9203 & 9433 & $2 \%$ & 38,00 \\
\hline 100 & M01W001A0011 & PANEL 40x80 KAPLAMA & $1.224,00$ & 783,55 & 440,45 & $35,98 \%$ & 23 & 48 & $109 \%$ & 25,50 \\
\hline 101 & M04CBO0A0011 & PARK BARIYERI & 98,25 & 70,57 & 27,68 & $28,17 \%$ & 1 & 3 & $200 \%$ & 32,75 \\
\hline 102 & M01FA00A0091 & PARKE KAMA & $6.360,00$ & $3.769,22$ & $2.590,78$ & $40,74 \%$ & 489 & 530 & $8 \%$ & 12,00 \\
\hline 103 & М0ЗРКСОА0011 & PKC400 KOFRA KUTUSU & $22.055,00$ & $19.947,59$ & $2.107,41$ & $9,56 \%$ & 1956 & 2005 & $3 \%$ & 11,00 \\
\hline 104 & M01BA00A0021 & PROFIL ADAPTÖRÜ ARKA & 792,00 & 716,67 & 75,33 & $9,51 \%$ & 68 & 72 & $6 \%$ & 11,00 \\
\hline 105 & M01BA00A0051 & PROFIL ADAPTÖRÜ DÜZ & $8.316,00$ & $5.303,32$ & $3.012,68$ & $36,23 \%$ & 201 & 216 & $7 \%$ & 38,50 \\
\hline 106 & M01BA00A0061 & PROFIL ADAPTÖRÜ ORTA & $1.335,00$ & 909,51 & 425,49 & $31,87 \%$ & 68 & 89 & $31 \%$ & 15,00 \\
\hline 107 & M01BA00A0031 & PROFIL ADAPTÖRÜ SAĞ & $2.136,00$ & $1.393,79$ & 742,21 & $34,75 \%$ & 58 & 89 & $53 \%$ & 24,00 \\
\hline 108 & M01BA00A0041 & PROFIL ADAPTÖRÜ SOL & $2.136,00$ & $1.393,79$ & 742,21 & $34,75 \%$ & 67 & 89 & $33 \%$ & 24,00 \\
\hline 109 & M02NG00A0041 & S2300Y DoĞALGAZ SERVIS KUTUSU ALT GÖVDE & $17.000,00$ & $9.559,32$ & $7.440,68$ & $43,77 \%$ & 850 & 1000 & $18 \%$ & 17,00 \\
\hline 110 & M02NG00A0021 & S2300Y DoĞALGAZ SERVIS KUTUSU ALT KAPAK & $13.000,00$ & $7.935,92$ & $5.064,08$ & $38,95 \%$ & 462 & 1000 & $116 \%$ & 13,00 \\
\hline 111 & M02NG00A0031 & S230oY DoĞALGAZ SERViS KUTUSU ÜST GÖVDE & $21.000,00$ & $16.905,02$ & $4.094,98$ & $19,50 \%$ & 795 & 1000 & $26 \%$ & 21,00 \\
\hline 112 & M02NG00A0011 & S2300Y DoĞALGAZ SERVVIS KUTUSU ÜST KAPAK & $15.000,00$ & $10.314,12$ & $4.685,88$ & $31,24 \%$ & 956 & 1000 & $5 \%$ & 15,00 \\
\hline 113 & M01RA00A0191 & SAÇAK ALTI KAPLAMA & $1.920,00$ & $1.584,62$ & 335,38 & $17,47 \%$ & 58 & 60 & $3 \%$ & 32,00 \\
\hline 114 & M02NG00A0201 & SHC330 DOĞALGAZ VANA KORUMA GÖVDE & 34,00 & 29,30 & 4,70 & $13,81 \%$ & 1 & 1 & $0 \%$ & 34,00 \\
\hline 115 & M02NG00A0191 & SHC330 DOĞALGAZ VANA KORUMA KAPAK & 21,00 & 16,30 & 4,70 & $22,36 \%$ & 1 & 1 & $0 \%$ & 21,00 \\
\hline 116 & M03SLA0A0041 & SLA SOKAK ARMATÜRÜ TAKIM & 108,00 & 88,12 & 19,88 & $18,40 \%$ & 3 & 6 & $100 \%$ & 18,00 \\
\hline 117 & M03SLG0A0031 & SLG ARA BÖLME & $5.157,00$ & $2.894,66$ & $2.262,34$ & $43,87 \%$ & 189 & 382 & $102 \%$ & 13,50 \\
\hline 118 & M03SLG0A0011 & SLG GÖVDE & $6.589,50$ & $4.433,81$ & $2.155,69$ & $32,71 \%$ & 276 & 382 & $38 \%$ & 17,25 \\
\hline 119 & M03SLG0A0021 & SLG KAPAK & $4.775,00$ & $3.033,09$ & $1.741,91$ & $36,48 \%$ & 368 & 382 & $4 \%$ & 12,50 \\
\hline 120 & M04WTOOA0016 & SU DEPOSU KAPAK $10 / 10 \mathrm{MM}$ & $1.475,00$ & 830,01 & 644,99 & $43,73 \%$ & 98 & 118 & $20 \%$ & 12,50 \\
\hline
\end{tabular}




\begin{tabular}{|c|c|c|c|c|c|c|c|c|c|c|}
\hline 121 & M01RA00A0201 & TAVAN LAMBIRI & 110,00 & 74,98 & 35,02 & $31,84 \%$ & 2 & 5 & $150 \%$ & 22,00 \\
\hline 122 & M01WA01A0021 & U PANEL PROFIL & $112.275,00$ & $76.114,21$ & $36.160,79$ & $32,21 \%$ & 5788 & 5988 & $3 \%$ & 18,75 \\
\hline 123 & M01WA00A0021 & ÜÇGEN ÜST KAPAK & $2.622,00$ & $1.795,38$ & 826,62 & $31,53 \%$ & 151 & 152 & $1 \%$ & 17,25 \\
\hline 124 & M01WA00A0011 & ÜST KAPAK & $90.298,00$ & $59.320,41$ & $30.977,59$ & $34,31 \%$ & 5986 & 6946 & $16 \%$ & 13,00 \\
\hline 125 & M01WA00A0011 & ÜST KAPAK & $36.751,00$ & $24.143,22$ & $12.607,78$ & $34,31 \%$ & 1960 & 2827 & $44 \%$ & 13,00 \\
\hline 126 & M05WC00A0021 & WC GIDER & $24.887,50$ & $15.174,06$ & $9.713,44$ & $39,03 \%$ & 867 & 905 & $4 \%$ & 27,50 \\
\hline 127 & M05WC00A0011 & WC ZEMIN & $70.590,00$ & $45.576,65$ & $25.013,35$ & $35,43 \%$ & 564 & 905 & $60 \%$ & 78,00 \\
\hline 128 & M01B000A0051 & 3.6 METRELIK I PROFIL & $13.694,00$ & $10.748,54$ & $2.945,46$ & $21,51 \%$ & 78 & 82 & $5 \%$ & 167,00 \\
\hline 129 & M01BA00A0071 & KUTU PROFIL 200x60x9 & 854,70 & 546,54 & 308,16 & $36,05 \%$ & 65 & 78 & $20 \%$ & 11,00 \\
\hline 130 & M01F000A0081 & 40 LIK ZEMIN TUĞLASI h:10cm & $36.482,00$ & $23.797,26$ & $12.684,74$ & $34,77 \%$ & 2111 & 2146 & $2 \%$ & 17,00 \\
\hline 131 & M01F000A0091 & 20 LiK ZEMIN TUĞLASI h:10cm & $7.020,00$ & $4.899,50$ & $2.120,50$ & $30,21 \%$ & 481 & 540 & $12 \%$ & 13,00 \\
\hline 132 & M01F000A0191 & 60x60 DÜZZEMIN PARÇASI H:10 cm & $7.215,00$ & $5.209,11$ & $2.005,89$ & $27,80 \%$ & 97 & 111 & $14 \%$ & 65,00 \\
\hline 133 & M01F000A0201 & 60x60 KENARZZMIN PARÇASI H:10 cm & $14.430,00$ & $10.329,79$ & $4.100,21$ & $28,41 \%$ & 189 & 222 & $17 \%$ & 65,00 \\
\hline 134 & M01F000A0211 & 60x60 Köş̧ ZEMin PARÇASI H:10 cm & $2.535,00$ & $1.819,88$ & 715,12 & $28,21 \%$ & 27 & 39 & $44 \%$ & 65,00 \\
\hline 135 & M01F000A0221 & 120x60 ZEMIN PARÇASI H:10 cm & $70.520,00$ & $65.176,99$ & $5.343,01$ & $7,58 \%$ & 750 & 820 & $9 \%$ & 86,00 \\
\hline 136 & M01FA00A0051 & KAMA & $136.521,00$ & $89.312,33$ & $47.208,67$ & $34,58 \%$ & 11462 & 12411 & $8 \%$ & 11,00 \\
\hline 137 & MO1FA00A0101 & 3.6 LIK ARAKAT KAMA & $96.187,00$ & $59.307,59$ & $36.879,41$ & $38,34 \%$ & 7249 & 7399 & $2 \%$ & 13,00 \\
\hline 138 & M01R000A0011 & BÜYÜK ÇATI KAPLAMASI & $2.220,00$ & $1.562,32$ & 657,68 & $29,63 \%$ & 28 & 30 & $7 \%$ & 74,00 \\
\hline 139 & M01R000A0011 & BÜYÜK ÇATI KAPLAMASI & $2.886,00$ & $2.031,02$ & 854,98 & $29,63 \%$ & 31 & 39 & $26 \%$ & 74,00 \\
\hline 140 & M01W000A0011 & 10 LUK TUĞLA & $10.881,00$ & $7.487,07$ & $3.393,93$ & $31,19 \%$ & 821 & 837 & $2 \%$ & 13,00 \\
\hline 141 & M01W000A0091 & 20 LiK YARIM TUĞLA HF & $97.747,00$ & $63.865,83$ & $33.881,17$ & $34,66 \%$ & 5238 & 7519 & $44 \%$ & 13,00 \\
\hline 142 & M01W000A0183 & 120x60 PANEL TUĞLA FDR & $3.700,00$ & $2.362,34$ & $1.337,66$ & $36,15 \%$ & 45 & 100 & $122 \%$ & 37,00 \\
\hline 143 & M01W000A0391 & 40x20 TUĞLA & $31.605,00$ & $21.690,55$ & $9.914,45$ & $31,37 \%$ & 1328 & 1505 & $13 \%$ & 21,00 \\
\hline 144 & M01W000A0411 & 160 LIK LENTO TUĞLASI & 316,00 & 231,45 & 84,55 & $26,76 \%$ & 5 & 8 & $60 \%$ & 39,50 \\
\hline 145 & M01W000A0431 & 120x60 PANEL ÇIFT YÖNLÜ KAPSÜL & $21.645,00$ & $16.351,87$ & $5.293,13$ & $24,45 \%$ & 458 & 555 & $21 \%$ & 39,00 \\
\hline 146 & M01W000A0441 & ÇiFT SIRA 20 LiK TUĞLA & $6.972,00$ & $4.318,07$ & $2.653,93$ & $38,07 \%$ & 135 & 332 & $146 \%$ & 21,00 \\
\hline 147 & M01W000A0451 & ÇiFT SIRA 40 LIK TUĞLA & $44.469,00$ & $29.945,97$ & $14.523,03$ & $32,66 \%$ & 1564 & 1647 & $5 \%$ & 27,00 \\
\hline 148 & Mo1W000A0461 & ÇIFT SIRA LENTO & $38.430,00$ & $28.270,01$ & $10.159,99$ & $26,44 \%$ & 562 & 732 & $30 \%$ & 52,50 \\
\hline 149 & M01W000A0471 & ÇiFT SIRA 20 LIK ZEMIN & $1.584,00$ & 893,45 & 690,55 & $43,60 \%$ & 41 & 66 & $61 \%$ & 24,00 \\
\hline 150 & M01W000A0481 & ÇiFT SIRA ZEMIN LENTO & $6.007,50$ & $3.697,06$ & $2.310,44$ & $38,46 \%$ & 65 & 89 & $37 \%$ & 67,50 \\
\hline 151 & M01W000A0491 & 120x60 PANEL BAĞ.ADAP. 40 LIK & 435,00 & 276,34 & 158,66 & $36,47 \%$ & 10 & 30 & $200 \%$ & 14,50 \\
\hline 152 & M01W000A0501 & 120x60 PANEL BAĞ.ADAP. 80 LIK & 510,00 & 341,65 & 168,35 & $33,01 \%$ & 11 & 30 & $173 \%$ & 17,00 \\
\hline 153 & Mo1 Woo0A0511 & PROFIL ALT KLIPS & $1.575,00$ & $1.026,75$ & 548,25 & $34,81 \%$ & 53 & 126 & $138 \%$ & 12,50 \\
\hline 154 & M01W000A0521 & PROFIL ÜST KLIPS & $1.575,00$ & $1.060,20$ & 514,80 & $32,69 \%$ & 59 & 126 & $114 \%$ & 12,50 \\
\hline 155 & Mo1WA01A0021 & U PANEL PROFIL & $7.650,00$ & $5.402,23$ & $2.247,77$ & $29,38 \%$ & 417 & 425 & $2 \%$ & 18,00 \\
\hline 156 & M01WA01A0431 & 40x20 TNK BMC TUĞLA & $25.232,00$ & $17.297,49$ & $7.934,51$ & $31,45 \%$ & 1209 & 1328 & $10 \%$ & 19,00 \\
\hline 157 & M01WA01A0431 & 40x20 TNK BMC TUĞLA & $11.495,00$ & $7.880,26$ & $3.614,74$ & $31,45 \%$ & 428 & 605 & $41 \%$ & 19,00 \\
\hline 158 & M02DC00A0081 & 40x60 MAZGAL KAPAK C250 & $29.925,00$ & $19.490,67$ & $10.434,33$ & $34,87 \%$ & 273 & 350 & $28 \%$ & 85,50 \\
\hline 159 & M02DC10A0071 & 40x60 MAZGAL TAKIM D400 & 100,00 & 79,44 & 20,56 & $20,56 \%$ & 1 & 1 & $0 \%$ & 100,00 \\
\hline 160 & M02DC10A0081 & 40x60 MAZGAL TAKIM C250 & 100,00 & 79,12 & 20,88 & $20,88 \%$ & 1 & 1 & $0 \%$ & 100,00 \\
\hline 161 & M02MHCOA0021 & ÇAP 69 ROGAR KAPAK C250 & 200,00 & 147,76 & 52,24 & $26,12 \%$ & 1 & 2 & $100 \%$ & 100,00 \\
\hline 162 & МО2МHСОАООЗ1 & ÇAP 69 ROGAR KAPAK B125 & 200,00 & 140,75 & 59,25 & $29,63 \%$ & 1 & 2 & $100 \%$ & 100,00 \\
\hline 163 & MO2MHCOA0071 & 60×80 TELEKOM KAPAK D400 & 253,00 & 161,78 & 91,22 & $36,05 \%$ & 16 & 23 & $44 \%$ & 11,00 \\
\hline 164 & MO2MHCOA0081 & 60×80 TELEKOM KAPAK C250 & 171,00 & 108,99 & 62,01 & $36,26 \%$ & 1 & 2 & $100 \%$ & 85,50 \\
\hline 165 & M02MHCOA0091 & 60x80 TELEKOM KAPAK B125 & 171,00 & 103,38 & 67,62 & $39,55 \%$ & 1 & 2 & $100 \%$ & 85,50 \\
\hline 166 & M02MHC1A0071 & 60×80 TELEKOM TAKIM D400 & $4.880,00$ & $3.314,44$ & $1.565,56$ & $32,08 \%$ & 16 & 40 & $150 \%$ & 122,00 \\
\hline 167 & M02MHC1A0071 & 60×80 TELEKOM TAKIM D400 & 220,00 & 140,68 & 79,32 & $36,05 \%$ & 17 & 20 & $18 \%$ & 11,00 \\
\hline 168 & МО2МHCAА0031 & 60x80 TELEKOM ÇERÇEVE & 136,00 & 102,23 & 33,77 & $24,83 \%$ & 3 & 4 & $33 \%$ & 34,00 \\
\hline 169 & M02MHCAA0031 & 60x80 TELEKOM ÇERÇEVE & 253,00 & 161,78 & 91,22 & $36,05 \%$ & 21 & 23 & $10 \%$ & 11,00 \\
\hline 170 & M02NG10A0011 & S2300Y DOĞALGAZ SERVIS KUTUSU TAKIM & $57.865,50$ & $38.699,43$ & $19.166,07$ & $33,12 \%$ & 1374 & 1503 & $9 \%$ & 38,50 \\
\hline 171 & M02SR10A0011 & TELEKOM ODASI TAKIM D400 & 190,00 & 141,03 & 48,97 & $25,77 \%$ & 2 & 2 & $0 \%$ & 95,00 \\
\hline 172 & M02SR10A0031 & TELEKOM ODASI TAKIM B125 & 880,00 & 562,72 & 317,28 & $36,05 \%$ & 43 & 80 & $86 \%$ & 11,00 \\
\hline 173 & M02SR10A0041 & TELEKOM ODASI TAKIM A15 & 90,00 & 64,05 & 25,95 & $28,83 \%$ & 1 & 1 & $0 \%$ & 90,00 \\
\hline 174 & M03SLG0A0041 & SLG SOKAK ARMATÜRÜ TAKIM & $86.835,00$ & $66.428,58$ & $20.406,42$ & $23,50 \%$ & 1905 & 2481 & $30 \%$ & 35,00 \\
\hline 175 & M04BCO0A0021 & ARABA ORTA TAMPONU & $18.018,00$ & $14.029,44$ & $3.988,56$ & $22,14 \%$ & 983 & 1001 & $2 \%$ & 18,00 \\
\hline 176 & М04HTO0A0011 & ÇEKIÇ & 390,00 & 278,14 & 111,86 & $28,68 \%$ & 8 & 26 & $225 \%$ & 15,00 \\
\hline 177 & M05M000A0011 & MAMA KABI 200×500×100 mm & $33.680,00$ & $23.342,61$ & $10.337,39$ & $30,69 \%$ & 1645 & 2105 & $28 \%$ & 16,00 \\
\hline 178 & M05MO00A0011 & MAMA KABI $200 \times 500 \times 100 \mathrm{~mm}$ & 368,00 & 254,44 & 113,56 & $30,86 \%$ & 7 & 23 & $229 \%$ & 16,00 \\
\hline 179 & Mo5WWOOA0011 & ÇERÇEVE PROFILI & 75,00 & 53,75 & 21,25 & $28,33 \%$ & 2 & 5 & $150 \%$ & 15,00 \\
\hline
\end{tabular}


İşletmenin toplam hasılatı 6.426.278,81 TL, ve mamullerin toplam katkısı 1.972.129,51 TL'dir. Bu durumda Ortalama Katk1 Oranı \% 30,69 olarak hesaplanmaktadır. Satışların büyüme hızı toplamı ise \%12457,22 ve mamul sayısı 179'dur. Bu nedenle ortalama büyüme hızı \% 69,59 olarak hesaplanmaktadır.

\subsection{Portföy Matrisinin Oluşturulması ve Yorumlanması}

Mamuller, katkı marjlarına ve satışlarının büyüme hızlarına göre matrise yerleştirilmiştir. Bu durumda portföy matrisi Şekil 1'deki gibidir.

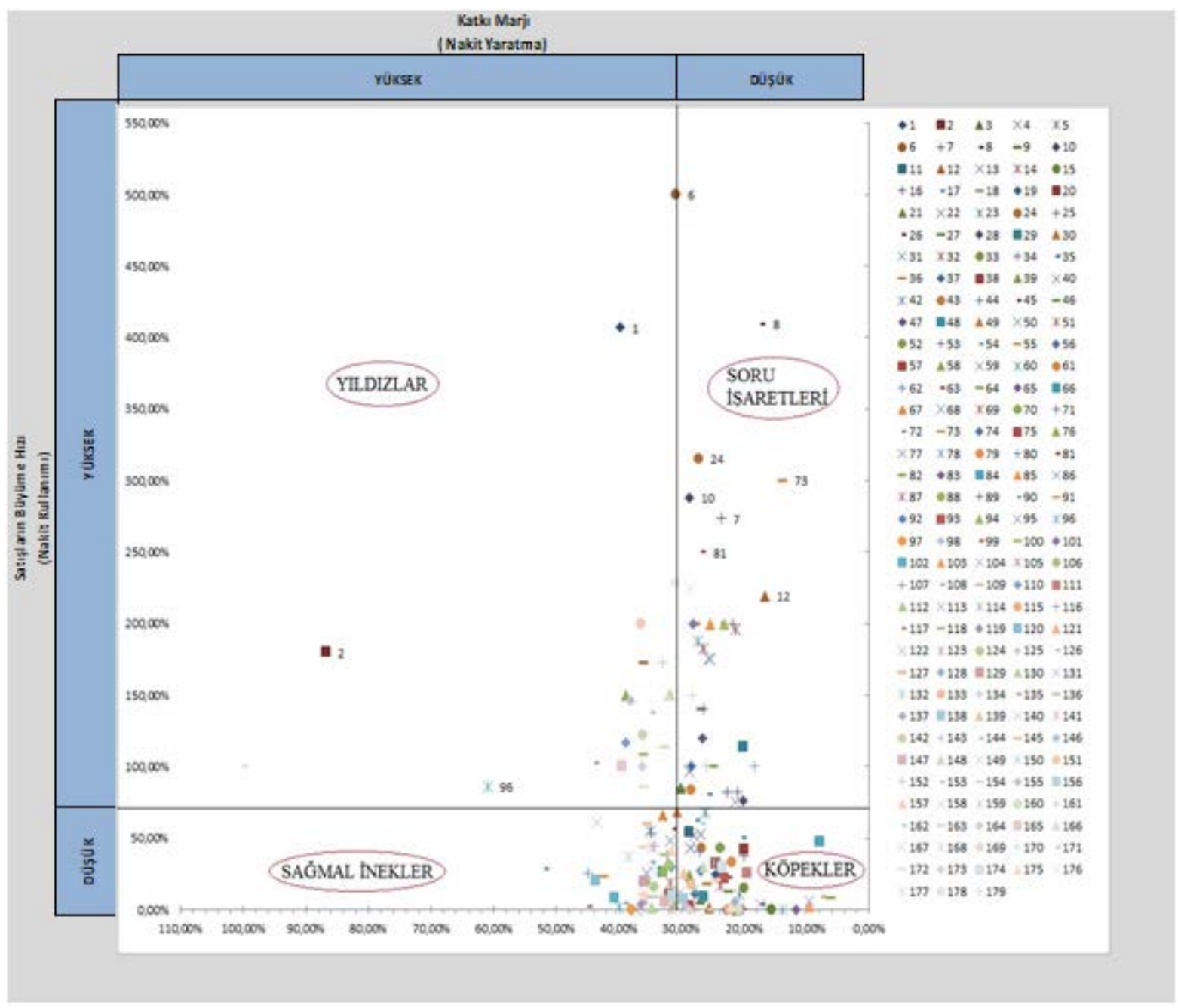

Şekil 1. ABC Kompozit Teknolojileri Sanayi ve Ticaret A.Ş BDG Mamul Portföy Matrisi 
Tablo 7. BDG Mamul Portföy Matrisi Sonuçları Detaylı Tablosu

\begin{tabular}{|c|c|c|c|c|c|c|c|c|c|c|c|}
\hline \multicolumn{3}{|c|}{ soru işaretleri } & \multicolumn{3}{|c|}{ köpekler } & \multicolumn{3}{|c|}{ yıldızlar } & \multicolumn{3}{|c|}{ Sağmal İnekler } \\
\hline NO & Katkı M. & Sat. B.H. & NO & Katkı M. & Sat. B.H. & NO & Katkı M. & Sat. B.H. & NO & Katkı M. & Sat. B.H. \\
\hline 27 & $30,20 \%$ & $84,62 \%$ & 23 & $26,14 \%$ & $67,51 \%$ & 2 & $86,71 \%$ & $180,00 \%$ & 90 & $51,93 \%$ & $28,57 \%$ \\
\hline 3 & $30,15 \%$ & $85,06 \%$ & 72 & $27,67 \%$ & $62,59 \%$ & 96 & $60,97 \%$ & $86,21 \%$ & 98 & $44,90 \%$ & $25,80 \%$ \\
\hline 162 & $29,63 \%$ & $100,00 \%$ & 144 & $26,76 \%$ & $60,00 \%$ & 117 & $43,87 \%$ & $102,12 \%$ & 99 & $44,90 \%$ & $2,50 \%$ \\
\hline 10 & $28,83 \%$ & $288,24 \%$ & 11 & $28,83 \%$ & $54,08 \%$ & 165 & $39,55 \%$ & $100,00 \%$ & 109 & $43,77 \%$ & $17,65 \%$ \\
\hline 59 & $28,83 \%$ & $96,39 \%$ & 22 & $26,90 \%$ & $53,06 \%$ & 110 & $38,95 \%$ & $116,45 \%$ & 120 & $43,73 \%$ & $20,41 \%$ \\
\hline 176 & $28,68 \%$ & $225,00 \%$ & 41 & $28,03 \%$ & $52,20 \%$ & 76 & $38,95 \%$ & $150,00 \%$ & 149 & $43,60 \%$ & $60,98 \%$ \\
\hline 56 & $28,54 \%$ & $100,00 \%$ & 54 & $20,37 \%$ & $50,72 \%$ & 146 & $38,07 \%$ & $145,93 \%$ & 91 & $42,35 \%$ & $23,08 \%$ \\
\hline 61 & $28,50 \%$ & $83,33 \%$ & 84 & $7,95 \%$ & $47,25 \%$ & 1 & $37,37 \%$ & $400,00 \%$ & 102 & $40,74 \%$ & $8,38 \%$ \\
\hline 179 & $28,33 \%$ & $150,00 \%$ & 134 & $28,21 \%$ & $44,44 \%$ & 151 & $36,47 \%$ & $200,00 \%$ & 78 & $39,89 \%$ & $1,60 \%$ \\
\hline 101 & $28,17 \%$ & $200,00 \%$ & 13 & $28,55 \%$ & $42,86 \%$ & 164 & $36,26 \%$ & $100,00 \%$ & 126 & $39,03 \%$ & $4,38 \%$ \\
\hline 55 & $27,77 \%$ & $200,00 \%$ & 43 & $26,76 \%$ & $42,86 \%$ & 142 & $36,15 \%$ & $122,22 \%$ & 150 & $38,46 \%$ & $36,92 \%$ \\
\hline 60 & $27,41 \%$ & $187,50 \%$ & 52 & $23,79 \%$ & $42,80 \%$ & 172 & $36,05 \%$ & $86,05 \%$ & 137 & $38,34 \%$ & $2,07 \%$ \\
\hline 24 & $27,29 \%$ & $315,38 \%$ & 38 & $20,01 \%$ & $42,41 \%$ & 100 & $35,98 \%$ & $108,70 \%$ & 97 & $37,97 \%$ & $0,00 \%$ \\
\hline 81 & $26,75 \%$ & $250,00 \%$ & 80 & $27,13 \%$ & $40,80 \%$ & 18 & $35,98 \%$ & $172,30 \%$ & 77 & $37,27 \%$ & $0,00 \%$ \\
\hline 9 & $26,74 \%$ & $140,00 \%$ & 34 & $19,96 \%$ & $37,93 \%$ & 153 & $34,81 \%$ & $137,74 \%$ & 119 & $36,48 \%$ & $3,80 \%$ \\
\hline 47 & $26,63 \%$ & $120,00 \%$ & 168 & $24,83 \%$ & $33,33 \%$ & 152 & $33,01 \%$ & $172,73 \%$ & 105 & $36,23 \%$ & $7,46 \%$ \\
\hline 62 & $26,56 \%$ & $140,00 \%$ & 79 & $22,01 \%$ & $33,33 \%$ & 154 & $32,69 \%$ & $113,56 \%$ & 163 & $36,05 \%$ & $43,75 \%$ \\
\hline 14 & $26,44 \%$ & $182,14 \%$ & 20 & $24,50 \%$ & $32,06 \%$ & 166 & $32,08 \%$ & $150,00 \%$ & 129 & $36,05 \%$ & $19,54 \%$ \\
\hline 161 & $26,12 \%$ & $100,00 \%$ & 148 & $26,44 \%$ & $30,25 \%$ & 121 & $31,84 \%$ & $150,00 \%$ & 169 & $36,05 \%$ & $9,52 \%$ \\
\hline 35 & $25,68 \%$ & $80,47 \%$ & 174 & $23,50 \%$ & $30,24 \%$ & 178 & $30,86 \%$ & $228,57 \%$ & 167 & $36,05 \%$ & $17,65 \%$ \\
\hline 31 & $25,61 \%$ & $175,64 \%$ & 92 & $27,01 \%$ & $27,27 \%$ & 6 & $30,84 \%$ & $500,00 \%$ & 71 & $35,76 \%$ & $8,30 \%$ \\
\hline 85 & $25,40 \%$ & $200,00 \%$ & 139 & $29,63 \%$ & $25,81 \%$ & & & & 70 & $35,76 \%$ & $19,45 \%$ \\
\hline 86 & $25,38 \%$ & $175,00 \%$ & 111 & $19,50 \%$ & $25,79 \%$ & & & & 50 & $35,50 \%$ & $25,68 \%$ \\
\hline 64 & $24,81 \%$ & $100,00 \%$ & 19 & $24,50 \%$ & $25,12 \%$ & & & & 127 & $35,43 \%$ & $60,46 \%$ \\
\hline 7 & $23,61 \%$ & $273,46 \%$ & 58 & $28,83 \%$ & $24,07 \%$ & & & & 5 & $34,91 \%$ & $54,95 \%$ \\
\hline 63 & $23,60 \%$ & $200,00 \%$ & 45 & $22,62 \%$ & $22,22 \%$ & & & & 158 & $34,87 \%$ & $28,21 \%$ \\
\hline 94 & $23,22 \%$ & $200,00 \%$ & 93 & $20,04 \%$ & $22,10 \%$ & & & & 130 & $34,77 \%$ & $1,66 \%$ \\
\hline 25 & $22,78 \%$ & $82,05 \%$ & 145 & $24,45 \%$ & $21,18 \%$ & & & & 107 & $34,75 \%$ & $53,45 \%$ \\
\hline 89 & $21,83 \%$ & $200,00 \%$ & 40 & $28,03 \%$ & $20,73 \%$ & & & & 108 & $34,75 \%$ & $32,84 \%$ \\
\hline 95 & $21,39 \%$ & $75,00 \%$ & 36 & $25,83 \%$ & $17,65 \%$ & & & & 141 & $34,66 \%$ & $43,55 \%$ \\
\hline 32 & $21,32 \%$ & $196,30 \%$ & 133 & $28,41 \%$ & $17,46 \%$ & & & & 136 & $34,58 \%$ & $8,28 \%$ \\
\hline 44 & $21,01 \%$ & $81,82 \%$ & 51 & $23,79 \%$ & $16,65 \%$ & & & & 125 & $34,31 \%$ & $44,23 \%$ \\
\hline 29 & $20,08 \%$ & $113,75 \%$ & 33 & $19,96 \%$ & $14,68 \%$ & & & & 124 & $34,31 \%$ & $16,04 \%$ \\
\hline 28 & $20,08 \%$ & $76,24 \%$ & 132 & $27,80 \%$ & $14,43 \%$ & & & & 170 & $33,12 \%$ & $9,39 \%$ \\
\hline 116 & $18,40 \%$ & $100,00 \%$ & 46 & $22,47 \%$ & $12,83 \%$ & & & & 67 & $32,97 \%$ & $66,43 \%$ \\
\hline 8 & $17,25 \%$ & $409,52 \%$ & 37 & $27,82 \%$ & $11,11 \%$ & & & & 66 & $32,97 \%$ & $26,08 \%$ \\
\hline 12 & $16,65 \%$ & $219,51 \%$ & 42 & $20,79 \%$ & $10,34 \%$ & & & & 88 & $32,87 \%$ & $26,24 \%$ \\
\hline 73 & $13,83 \%$ & $300,00 \%$ & 135 & $7,58 \%$ & $9,33 \%$ & & & & 118 & $32,71 \%$ & $38,41 \%$ \\
\hline & & & 48 & $26,50 \%$ & $8,70 \%$ & & & & 147 & $32,66 \%$ & $5,31 \%$ \\
\hline & & & 82 & $6,13 \%$ & $7,94 \%$ & & & & 16 & $32,31 \%$ & $37,80 \%$ \\
\hline & & & 4 & $30,15 \%$ & $7,41 \%$ & & & & 122 & $32,21 \%$ & $3,46 \%$ \\
\hline & & & 21 & $26,90 \%$ & $7,28 \%$ & & & & 75 & $31,90 \%$ & $10,67 \%$ \\
\hline & & & 138 & $29,63 \%$ & $7,14 \%$ & & & & 106 & $31,87 \%$ & $30,88 \%$ \\
\hline & & & 104 & $9,51 \%$ & $5,88 \%$ & & & & 68 & $31,85 \%$ & $48,22 \%$ \\
\hline & & & 128 & $21,51 \%$ & $5,13 \%$ & & & & 69 & $31,85 \%$ & $18,51 \%$ \\
\hline & & & 17 & $17,34 \%$ & $3,57 \%$ & & & & 74 & $31,64 \%$ & $30,11 \%$ \\
\hline & & & 113 & $17,47 \%$ & $3,45 \%$ & & & & 123 & $31,53 \%$ & $0,66 \%$ \\
\hline & & & 87 & $28,24 \%$ & $2,67 \%$ & & & & 156 & $31,45 \%$ & $9,84 \%$ \\
\hline & & & 103 & $9,56 \%$ & $2,51 \%$ & & & & 157 & $31,45 \%$ & $41,36 \%$ \\
\hline & & & 57 & $28,83 \%$ & $1,93 \%$ & & & & 143 & $31,37 \%$ & $13,33 \%$ \\
\hline & & & 155 & $29,38 \%$ & $1,92 \%$ & & & & 26 & $31,26 \%$ & $56,41 \%$ \\
\hline & & & 175 & $22,14 \%$ & $1,83 \%$ & & & & 112 & $31,24 \%$ & $4,60 \%$ \\
\hline & & & 30 & $25,61 \%$ & $1,20 \%$ & & & & 140 & $31,19 \%$ & $1,95 \%$ \\
\hline & & & 53 & $20,37 \%$ & $0,74 \%$ & & & & 49 & $30,74 \%$ & $68,42 \%$ \\
\hline & & & 173 & $28,83 \%$ & $0,00 \%$ & & & & 177 & $30,69 \%$ & $27,96 \%$ \\
\hline & & & 171 & $25,77 \%$ & $0,00 \%$ & & & & 131 & $30,21 \%$ & $12,27 \%$ \\
\hline & & & 65 & $22,92 \%$ & $0,00 \%$ & & & & & & \\
\hline & & & 115 & $22,36 \%$ & $0,00 \%$ & & & & & & \\
\hline & & & 39 & $21,26 \%$ & $0,00 \%$ & & & & & & \\
\hline & & & 160 & $20,88 \%$ & $0,00 \%$ & & & & & & \\
\hline & & & 159 & $20,56 \%$ & $0,00 \%$ & & & & & & \\
\hline & & & 15 & $15,63 \%$ & $0,00 \%$ & & & & & & \\
\hline & & & 114 & $13,81 \%$ & $0,00 \%$ & & & & & & \\
\hline & & & 83 & $11,63 \%$ & $0,00 \%$ & & & & & & \\
\hline
\end{tabular}


Matriste, 38 adet mamul soru işaretlerinde, 64 adet mamul uyuz köpeklerde, 23 adet mamul yıldızlarda ve 58 adet mamul sağmal nakit ineklerinde yer almaktadır. Bu mamuller için karar verilirken, kendi içerisindeki durumları değerlendirilerek, gelecekteki durumları hakkında tahminde bulunmak gerekmektedir. Yorumlamalar Tablo 8'deki siralamalar göz önünde bulundurularak yapılabilecektir.

Tablo 8. Mamuller için Matris Üzerinde Başarı ve Felaket Sıralaması
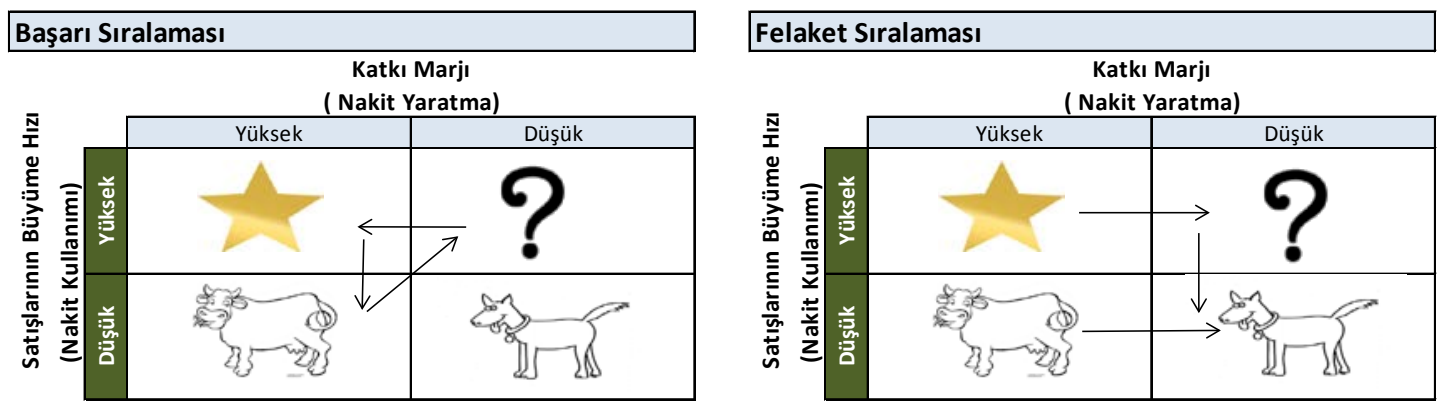

Örneğin soru işaretlerinde ortalama katkı marjının altında kalan mamulleri, bu eşik değerin üstüne taşımak hedeflenecektir. Bu nedenle ortalama katkı marj1 \%30,69'a en yakın mamullerin, değişken genel imalat maliyetlerini düşürecek stratejiler geliştirilebilir. Buna karşın katkı marjı oldukça düşük fakat satışların büyüme hızı çok yüksek olan (8 nolu mamul gibi) mamullerde göz önünde bulundurulmalıdır. Köpeklerde yer alan mamuller için en iyi durum soru işaretlerine taşınabilmesi olacaktır. Bu nedenle satışların büyüme yüzdesi en yüksek olanlar için strateji geliştirilebilecektir. Yıldız mamuller için, katkı marjının yüksek tutulmaya çalışılması ve mamullerin soru işaretleri bölgesine geçmemesi sağlanmalıdır. Örneğin 178 ve 6 nolu mamullerin katkı marjları, eşik değere çok yakındır ve soru işaretleri bölgesine geçme ihtimali bulunmaktadır. $\mathrm{Bu}$ nedenle maliyet kontrolü sağlanmalıdır. Yıldızlarda ki en muhtemel sorun ise, katkı marjının yine \% 30,69'un altında kalması ve mamullerin uyuz köpekler bölgesinde kalmasıdır. Şirketin sağmal nakit ineklerindeki mamulleri incelendiğinde, bu risk ile karşı karşıya olan pek çok mamul bulunduğu görülmektedir. Değişken imalat maliyetlerinin düşürülmesi hususunda çalışılmalıdır.

\section{SONUÇ VE ÖNERILER}

İşletmelerin rekabete ayak uydurma sürecindeki en önemli anahtarlarından birisi, mamullerinin maliyet kontrollerini sağlamak ve satış hacmini geliştirmektir. Diğer bir deyişle yüksek kâr elde etmektir. Bu nedenle yönetim ve maliyet muhasebesi kararları oldukça önemlidir. Boston Danışma Grubu (BDG) tarafından geliştirilen ve uzun yıllardır pazarlama ve stratejik yönetim alanlarında kullanılan portföy matrisinin, üretim yapan işletmelerdeki mamuller hakkındaki yönetim muhasebesi kararlarında kullanılabilirliği araştırılmıştır.

Pazarlama ve stratejik yönetimdeki BDG portföy matrisinden farklı olarak, göreceli Pazar payı yerine mamullerin katkı marjları, pazarın büyüme hızı yerine ise mamulün satışlarının büyüme hızı kullanılmıştır. Mamullerin satışların büyüme hızı, önceki yıllara göre satışlarının artışı dikkate alınarak hesaplanırken, katkı marjları ise, değişken maliyetler ve satış fiyatı dikkate alınarak hesaplanmıştır. Mamuller hesaplamalar sonucunda aldığ değerlere göre, BDG Mamul Portföy Matrisine yerleştirilmiştir. Böylece 38 adet mamul soru işaretlerinde, 64 adet mamul köpeklerde, 23 adet mamul yıldızlarda ve 58 adet mamul ise 
sağmal nakit ineklerinde yer almıştır. Mamuller, matristeki yer aldıkları bölgelere göre yorumlanmıştır. Sonuç olarak işletmenin sağmal nakit ineklerindeki bazı mamullerin, uyuz köpeklere düşme riskinin olduğu, bazı soru işaretindeki mamullerin yıldızlara taşınabilme ihtimali olduğu görülmüştür. Bu sonuçlar işletmenin değişken maliyetlerinin kontrolünü sağlamada ve uygun satış fiyatı belirlemede önemli bir gösterge oluşturmaktadır.

BDG mamul portföy matrisinin, yönetim muhasebesi kararlarındaki etkinliğinin tespit edilebilmesi için, birkaç farklı işletmede ve birkaç dönemi kapsayacak şekilde çalışma yapılması gerekmektedir. İşletme yönetiminin mamuller üzerinde aldıkları kararlar ile, dönemsel matrislerin ve güncel durumun karşılaştırması ve uygulanabilecek anketler sonucunda, etkinliği hakkında karar verilebilecektir. Fakat bu çalışma ile, BDG matrisinin, yönetim muhasebesi kararlarında uygulanabilirliğinin olduğu ve yönetimin bilgilendirilmesi açısından uygun bir yaklaşım olduğu görülebilmektedir.

\section{KAYNAKÇA}

Barald1, E. - Brennan, R. - Harrıson, D. - Tunısını, A. Ve Zolkıewskı ,J. (2007), "Strategic Thinking And The Imp Approach: A Comparative Analysis”, Industrial Marketing Management, No: 36.

Collıs, James - Montgomery, Cynthia (1997), Corporate Strategy: Resources And The Scope Of The Firm, Irwin Mcgraw- Hill.

Çetinkaya, Özlem (2006), "Rekabet Stratejilerinin Belirlenmesinde Portföy Analizi Ve Tariş Üzerine Bir Araştırma," Gazi Üniversitesi İktisadi Ve İdari Bilimler Fakültesi Dergisi, Say1 8-3, ss. 57-76.

Eren, Erol (2013), Stratejik Yönetim Ve İşletme Politikası, Beta Yayıncılık, İstanbul.

Kotler, Philip - Armstrong, Gary (2012), Principles Of Marketing, Pearson Education Gate, England.

Miller, Alex (1998), Strategic Management, Mcgraw- Hill, Boston.

Porter, Micheael,E. (2000), Rekabet Stratejisi, Çev. Gülen Ulubilgen, Sistem Yayıncılık, İstanbul.

Ülgen, Hayri - Mirze, Kadri (2013), İşletmelerde Stratejik Yönetim, Beta Yayınları, İstanbul.

Yükçü, Süleyman (2011) ,Yönetim Açısından Maliyet Muhasebesi, Altın Nokta Yayınları, İzmir.

Yükselen, Cemal (2010), Pazarlama İlkeler-Yönetim-Örnek Olaylar, Detay Yayıncıllk, 8. Bask1, Ankara.

https://www.bcgperspectives.com/content/Classics/strategy_the_product_portfolio, (Erişim Tarihi 15.04.2015 ). 
The Journal of Accounting and Finance- August 2019 Special Issue 527-544 